\title{
Dam Breach Analysis Using HEC-RAS and HEC-GeoRAS: The Case of Kesem Kebena Dam
}

\author{
Abimael Leoul, Nebiyou Kassahun \\ Hydraulic Engineering Department, Institute of Technology College, Debre Markos University, Debre Markos, Ethiopia \\ Email: abileoul@gmail.com, nebiyou_kassahun@dmu.edu.et
}

How to cite this paper: Leoul, A. and Kassahun, N. (2019) Dam Breach Analysis Using HEC-RAS and HEC-GeoRAS: The Case of Kesem Kebena Dam. Open Journal of Modern Hydrology, 9, 113-142. https://doi.org/10.4236/ojmh.2019.94007

Received: August 15, 2019

Accepted: October 8, 2019

Published: October 11, 2019

Copyright ( 2019 by author(s) and Scientific Research Publishing Inc. This work is licensed under the Creative Commons Attribution International License (CC BY 4.0).

http://creativecommons.org/licenses/by/4.0/ (c) (1) Open Access

\begin{abstract}
Ethiopia has been booming with active construction of dams within the past few decades for different infrastructural needs, but has never experienced demolition or failure of dams in its history; hence little attention is being given to possible breach scenarios of dams and the resulting floodings. This paper makes analysis of the possible breach of kesem dam and the resulting flood inundation. In this study, the dam has been checked for both overtopping and piping failure modes using one dimensional river analysis model called HEC-RAS. Empirical equations were used to predict dam breach parameters of the two failure modes for use in this model. PMF inflow with a peak $9237.77 \mathrm{~m}^{3} / \mathrm{s}$ is used as an input to the reservoir to check if overtopping failure was possible. The spill way has proven to have adequate capacity for the flood due to the PMF. Therefore, breaching of the embankment was not possible. Piping failure was also simulated in HEC-RAS and the resulting breach due to piping failure, was analyzed and flood hydrograph was obtained at different cross sections along the river. These are flood hydrographs at $20 \mathrm{~km}, 40 \mathrm{~km}$ and $60 \mathrm{~km}$ at the downstream. The resulting flood plain was also mapped using HEC-GeoRas to show the extent of flooding.
\end{abstract}

\section{Keywords}

Dam Breach Analysis, Flood Mapping, HEC-RAS, HEC-GeoRAS

\section{Introduction}

While dams provide the ability to control the flow of fresh water and function to simplify our lives in many ways, they also pose an inherent and inevitable threat to the environment and to public safety. Since the creation of the first dams, dams have been failing due to unpredictable environmental conditions, poor engineering, or improper management. Unfortunately, when dams fail they often 
do so catastrophically because of the large amount of potential energy involved.

Dams are complex structures subjected to several forces that can cause failure, these forces are active over the entire life of the dam, and failures of dames controlled or uncontrolled is inevitable. Many efforts have been made to reduce the potential hazard of dams as well as to provide emergency action plans for the event of a dam failure. Dam breach analysis can provide basic information about flood events that can be beneficial in dam engineering, emergency action planning, and floodplain management.

Different organizations and researchers have contributed their findings in the analysis of dam break and its consequence. They have derived regression equations based on data from historical dam failure events that are used in predicting the breach geometry. This includes Macdonald and Langridge Monopolies and Froehlich empirical relations. Development of analytical models using the principle of hydraulics and sediment transport; are also useful in simulating the breach process and downstream flooding.

Kesem dam and irrigation project is located $225 \mathrm{~km} \mathrm{E}$ of Addis Ababa, Ethiopia and $40 \mathrm{~km} \mathrm{NW}$ of Metehara town. The Kesem river catchment covers about $3000 \mathrm{~km}^{2}$ area and extends from an altitude of almost $3600 \mathrm{~m}$ down to $860 \mathrm{~m}$ a.m.s.l. The project involves $90 \mathrm{~m}$ high rock earth fill dam to impound half a billion-cubic meter of water to irrigate 20,000 hectares of land for sugar cane plantation [1]. Since small towns and sugarcane plantations are present downstream of the dam, dam breach analysis should be done as a precaution for reasons that may result due to dam failure.

In Ethiopia, a contrary vigorously engaged in the development of dams, such per event analysis is not being carried out as part of the project by designers or researchers. However, dam breach modelling needs to be customary design procedure to identify the possible causes of dam failure, simulate the breaching process so that design parameters can be reviewed. And in the event of failure map the area that will be flooded to demarcate prone areas while planning the downstream area for various infrastructures, alert concerned bodies to a precaution on dam safety plans and formulate a hazard management system. Therefore, in our current case of Kesem Dam breach analysis a scenario is selected and outflow hydrograph from the breach is routed which results in a flood inundated map on the downstream side of the dam.

\section{Materials and Method}

The methodology adopted in this study includes, data collection, organization and analysis of data using modeling software.

\section{DATA USED}

DEM: Dam breach analysis involves routing the outflow hydrograph from the breached dam throughout downstream of the river from the dam up to the downstream boundary, this will require elevation data of the reservoir and elevation data of the cross section of the river including the flood plain. Digital Elevation Model (DEM) of $30 \times 30$ is used as a source of elevation data for this study. 
LULC: Once a dam breach takes place, the original river cross section on the downstream as well as a large area of flood plain of the river on the left and right side will be inundated and will act as a channel to convey the flood wave as it travels to the downstream. The land use and land cover will define the channel characteristics of the flood plain during flooding. Therefore, the estimation of Manning's channel roughness coefficient is based on land use land cover map of the flood plain on the downstream.

PRECIPTATION: the breaching event is considered during an extreme flood (probable maximum flood/PMF) event entering the reservoir, that results from extreme precipitation scenario obtained from frequency analysis of historical records of precipitation.

SOFTWERE: HEC-RAS and HEC-GoeRAS are used in conjunction for hydraulic modeling.

\subsection{Dam Breach Parameter}

The estimation of possible breach dimensions and development time is also necessary in any assessment of dam safety since breach parameters will directly and substantially affect the estimate of the flow, inundated areas and warning time at the downstream locations [2].

The available breach parameter and peak breach flow estimation techniques can be classified into three categories, as follows: Comparative analysis, Regression-based methods based on data collected from actual dam failures, and Physically-based simulation models [3]. Table 1 shows the Regression-based methods of detailed dam breach parameter estimations using Mac Donald and Langirdge-Monopolis and Froehlich's equations.

Agency guidelines are generally in the form of suggested ranges [4] or conservative upper bound estimates. Therefore, they do not appear to be intended for obtaining accurate breach flow estimates. The physically-based embankment dam breach models, such as BREACH [5] and BEED [6] rely on bed-load type

Table 1. MacDonald and Langridge-Monopolis (1984) and Froehlich (2008) empirical equations.

\begin{tabular}{|c|c|c|}
\hline Breach Parameters & $\begin{array}{l}\text { MacDonald and } \\
\text { Langridge-Monopolis (1984) }\end{array}$ & Froehlich (2008) \\
\hline $\begin{array}{l}\text { Volume Eroded } \\
\qquad \begin{array}{c}V_{e r} \\
\left(\mathrm{~m}^{3}\right)\end{array}\end{array}$ & $\begin{array}{c}V_{e r}=0.0261\left(V_{\text {out }} \times h_{w}\right)^{0.769} \\
(\text { earth fill }) \\
V_{e r}=0.00348\left(V_{\text {out }} \times h_{w}\right)^{0.852} \\
(\text { rock fill })\end{array}$ & \\
\hline $\begin{array}{c}\text { Breach Width } \\
\qquad B \\
(\mathrm{~m})\end{array}$ & $B_{b}=\frac{V_{e r}-H_{b}^{2}\left(C Z_{b}+\frac{H_{b} Z_{b} C_{3}}{3}\right)}{H_{b}\left(C+\frac{H_{b} Z_{3}}{2}\right)}$ & $\begin{array}{c}B_{\text {avg }}=0.27 K_{o} V_{w}^{0.32} H_{b}^{0.04} \\
K_{o}=1.0 \text { for piping } \\
K_{o}=1.3 \text { for overtopping }\end{array}$ \\
\hline $\begin{array}{l}\text { Breach Side Slope } \\
\qquad(H: V)\end{array}$ & $0.5: 1$ & $\begin{array}{c}\text { 0.7:1 piping } \\
\text { 1.0:1 overtopping }\end{array}$ \\
\hline
\end{tabular}


erosion formulas, which may be appropriate for some stages of the breach process, but are not consistent with the mechanics of much of the breaching process as observed in the field or laboratory (Wahl 1988). Therefore, in practice, most widely used methods for predicting breach parameters are based on regression analyses of data collected from dam failures [3].

In this study, the MacDonald and Langridge-Monopolis (1984) and Froehlich (2008) empirical formulas, which are developed from regression analysis of data collected from various dam failure experiences, are used to estimate the Dam breach parameters of Kesem Dam.

\subsection{Hydraulic Model Development}

\subsubsection{HEC-GeoRAS Modeling}

HEC-GeoRAS is a set of ArcGIS tool specifically designed to process geospatial data to be used with the Hydrologic Engineering Center's River Analysis System (HEC-RAS) software. The extension allows users to create an HEC-RAS import file containing geometric data from an existing digital elevation model (DEM) [7].

Essential data required to work with HEC-GeoRAS are terrain data (Digital Elevation Model DEM) and land use information. The geometry file for HECRAS contains information on cross-sections, hydraulic structures, river banks and other physical attributes of river channels. The pre-processing using HECGeoRAS involves creating these attributes in GIS, and then exporting them to the HEC-RAS geometry file. In HEC-GeoRAS, each attribute is stored in a separate feature class called RAS Layer [7]. These RAS layers are added to the map document with a pre-assigned semiology. Since these layers are empty they are populated by digitizing each layer.

The Stream Centerline layer is used to identify the connectivity of the river system. It is created in the downstream direction and is used to assign river stations to the cross sections, bridges, and other structures to order of computational nodes in the HEC-RAS model. The Cross-Sectional Cut Lines layer is the principal data constructed using HEC-GeoRAS. Cut lines are digitized across the floodplain area to capture the profile of the land surface. Cross sections should be digitized perpendicular to the path of flow in the channel and overbank areas to be consistent with one-dimensional flow characteristics. A summary of RAS Layers and their use in building a hydraulic model is provided in Table 2, whereas their geometrical orientation is shown in Figure 1.

The final task before exporting the GIS data to HEC-RAS geometry file is assigning Manning's $\mathrm{n}$ value to individual cross-sections. HEC-GeoRAS accomplishes this by using a land use feature class with Manning's " $n$ " value stored for different land use types. Figure 2 shows cross section cutline of Kesem River and their corresponding land use.

\subsubsection{HEC-RAS Modeling}

HEC-RAS is a one-dimensional river hydraulics model used for steady-flow and 
Table 2. Summary of HEC-GeoRAS layers and corresponding output for HEC-RAS.

\begin{tabular}{ll}
\hline \multicolumn{1}{c}{ RAS layers } & \multicolumn{1}{c}{ Description } \\
\hline Stream Centerline & $\begin{array}{l}\text { Used to identify the connectivity of the river network and assign river } \\
\text { stations to computation points. }\end{array}$ \\
Cross-Sectional Cut Lines & $\begin{array}{l}\text { Used to extract elevation transects from the DEM at specified } \\
\text { locations and other cross-sectional properties. } \\
\text { Bank Lines }\end{array}$ \\
Elow Path Centerlines & $\begin{array}{l}\text { Used to identify the center of mass of flowin the main channel and } \\
\text { overbanks to compute the downstream reach lengths between cross } \\
\text { sections. }\end{array}$ \\
Land Use & $\begin{array}{l}\text { Used to assign flow roughness factors (Manning's } n \text { values) to the } \\
\text { cross sections. }\end{array}$ \\
Inline Structures & $\begin{array}{l}\text { Used to extract the weir profile from the DEM for inline structures } \\
\text { (dams). }\end{array}$ \\
\hline
\end{tabular}

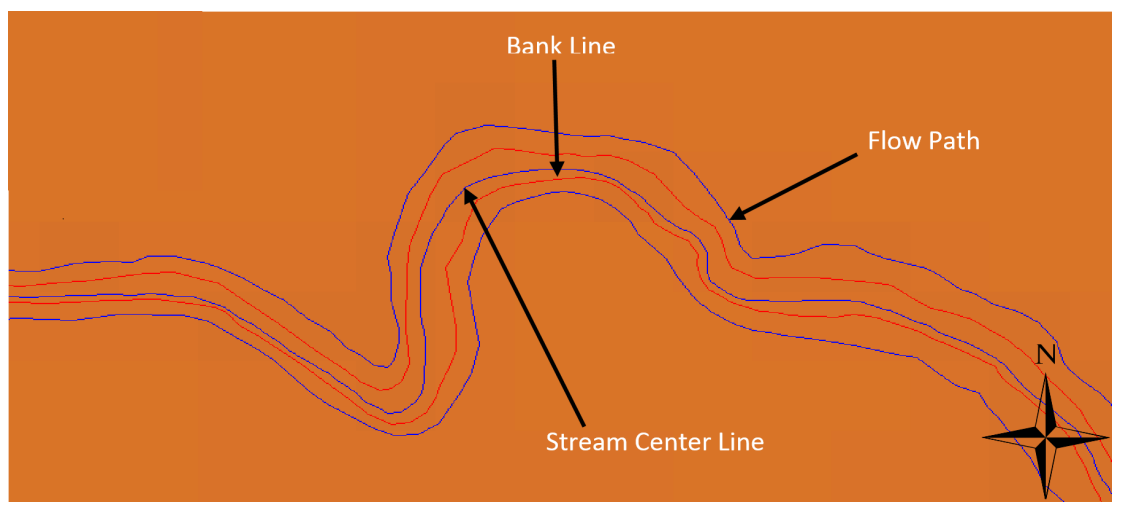

Figure 1. Stream Centerline, Bank Lines and Flow Path layers digitized in HEC-GeoRAS tool.

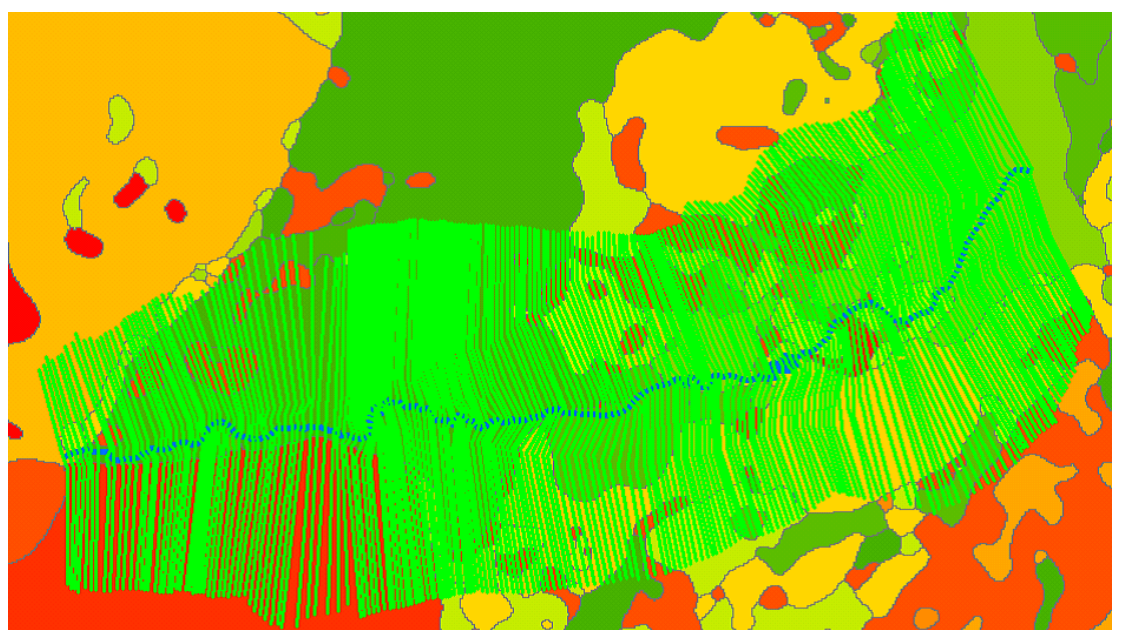

Figure 2. Cross section cut lines of Kesem River and land use layer of the study area.

unsteady-flow water surface profile computations through a network of open channels [8]. Because HEC-RAS solves the full Saint-Venant equations, it is well 
suited for computing the flood wave propagation resulting from a dam failure scenario [9].

\section{1) Dam Profile}

A dam is modeled in HEC-RAS as an inline structure. An inline structure is represented with a weir profile (that includes the spillway). An inline structure can be directly added to HEC-RAS or it can be imported from ARCGIS together with other geometric data. In this study, the inline stricture is imported from ARCGIS.

Inline structure data are entered in HEC-RAS. This data includes a weir/Embankment profile, and any gated spillways that may be modeled [8]. In this study only weir and Embankment profile are entered since the spillway is not gated. Figure 3 shows profile of Kesem dam as an in-line structure in HEC-RAC.

\section{2) Dam Breach Data}

To model dam failure in HEC-RAS Dam Breach parameters (breach shape and formation time) estimated using different empirical formulas and failure mode are entered in HEC-RAS. Since HEC-RAS supports both over toping and piping failure mode, breach parameters estimated for each failure mode is used for dam failure modeling in HEC-RAS. Data entry of breach information for Kesem dam in HEC-RAS is shown in Figure 4.

\section{Channel Cross Section data}

Cross sections are one of the key inputs to HEC-RAS. Cross sections are digitized in ArcGIS using the HEC-GeoRAS tool and are imported into HEC-RAS along with other geometric data. Cross section cut lines are used to extract elevation data from the terrain to create cross sectional profile across the channel flow [10]. The intersection of cut lines with HEC-GeoRAS layers such as centerline and flow path lines are used to compute HEC-RAS attributes such as bank station (locations that separate channel from flood plain), downstream reach length (distance between cross sections) and Mannings ( $n$ ) [10]. Cross sections provide useful information such as elevation across the flood plain, station points and Mannings roughness coefficient which are then used for Dam Breach analysis in HEC-RAS. In this study, cross section cut lines are digitized every $200 \mathrm{~m}$ along

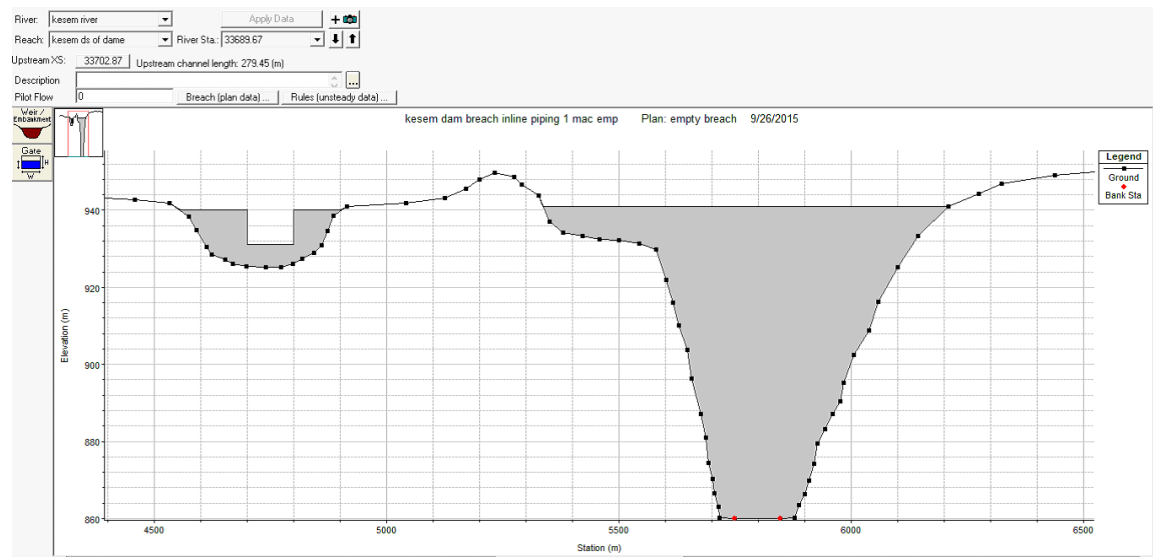

Figure 3. Cross sectional profile of Kesem dam in HEC-RAS. 


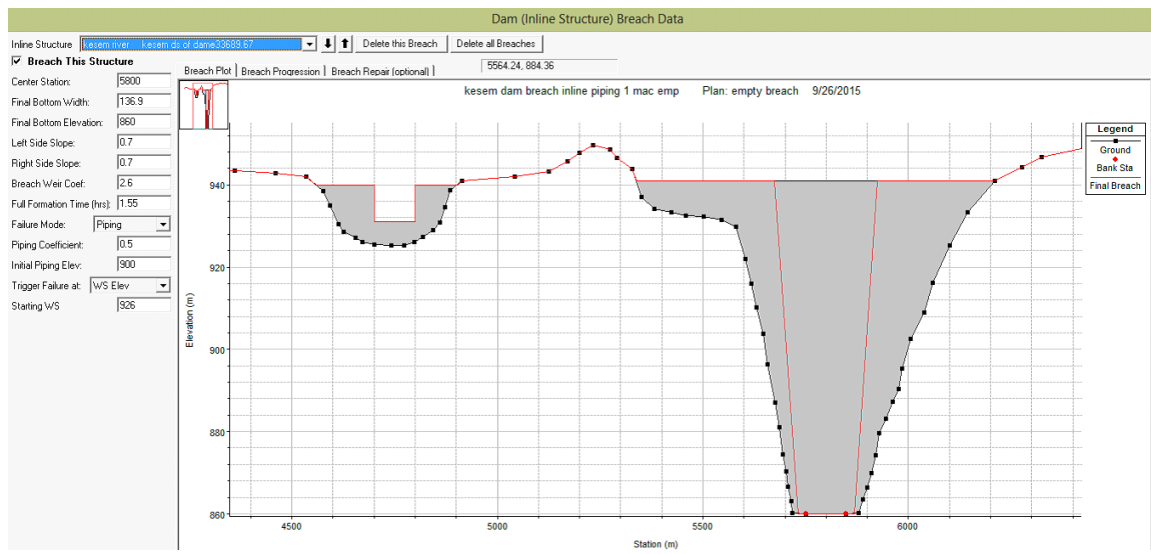

Figure 4. Dam breach data of Kesem dam in HEC-RAS.

downstream of the river from the dam up to the downstream boundary $60 \mathrm{~km}$ from the dam. Figure 5 shows cross section cutline across Kesem River and other geometric data in HEC-RAS.

\section{3) Unsteady flow analysis}

Flood is a typical example of unsteady flow since the stage of the flow changes instantaneously as the flood wave passes by [11]. In this study HEC-RAS is used to simulate unsteady flow throughout the downstream of Kesem River from Kesem dam up to the downstream boundary $60 \mathrm{~km}$ from the dam. Once all of the geometric data are entered in to HEC-RAS, required unsteady flow data must be entered to undertake the unsteady flood simulation. Unsteady flow data includes boundary conditions at all of the external boundaries of the system, as well as any desired internal locations, and set the initial flow and storage area condition at the beginning of the simulation. Generally unsteady flow data required are boundary condition and initial condition.

There are different types of boundary conditions some of them are Flow Hydrograph, Stage Hydrograph, Stage and Flow hydrograph, Rating Curve, Normal Depth, Lateral Inflow hydrograph etc. Unsteady flow data used as a boundary condition in this study are PMF Inflow Hydrograph (Appendix 1) and Normal depth. The PMF Inflow Hydrograph is used as an upstream boundary condition. Inflow Hydrograph boundary condition of Kesem River and its plot are shown on Figure 6. Normal depth is used as a downstream boundary condition. Normal depth can only be used as a downstream boundary condition for an openended reach. To use normal depth, it is required to enter a fraction slope for the reach in the vicinity of the boundary. The slope of the water surface is often a good estimate of the friction slope [8].

In addition to the boundary condition, initial condition should be established at the beginning of the unsteady flow simulation. Initial condition consists of flow and stage information at each of the cross sections, as well as elevations for any storage areas defined in the system [8]. Once all the geometric and unsteady flow data have been entered, unsteady flow calculations can be performed. 


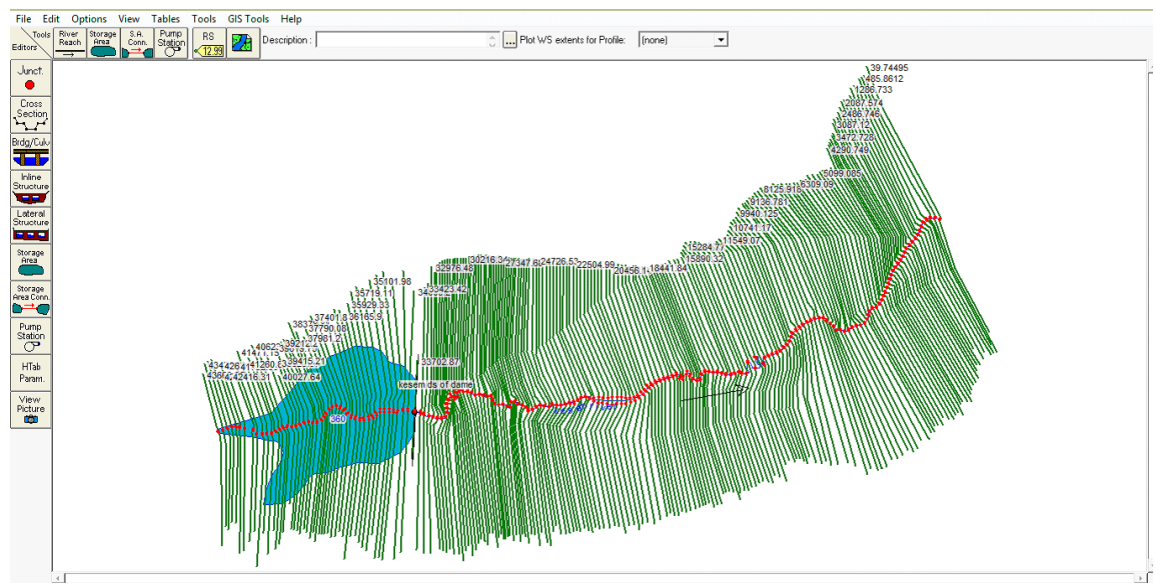

Figure 5. Cross section cutline across Kesem River.

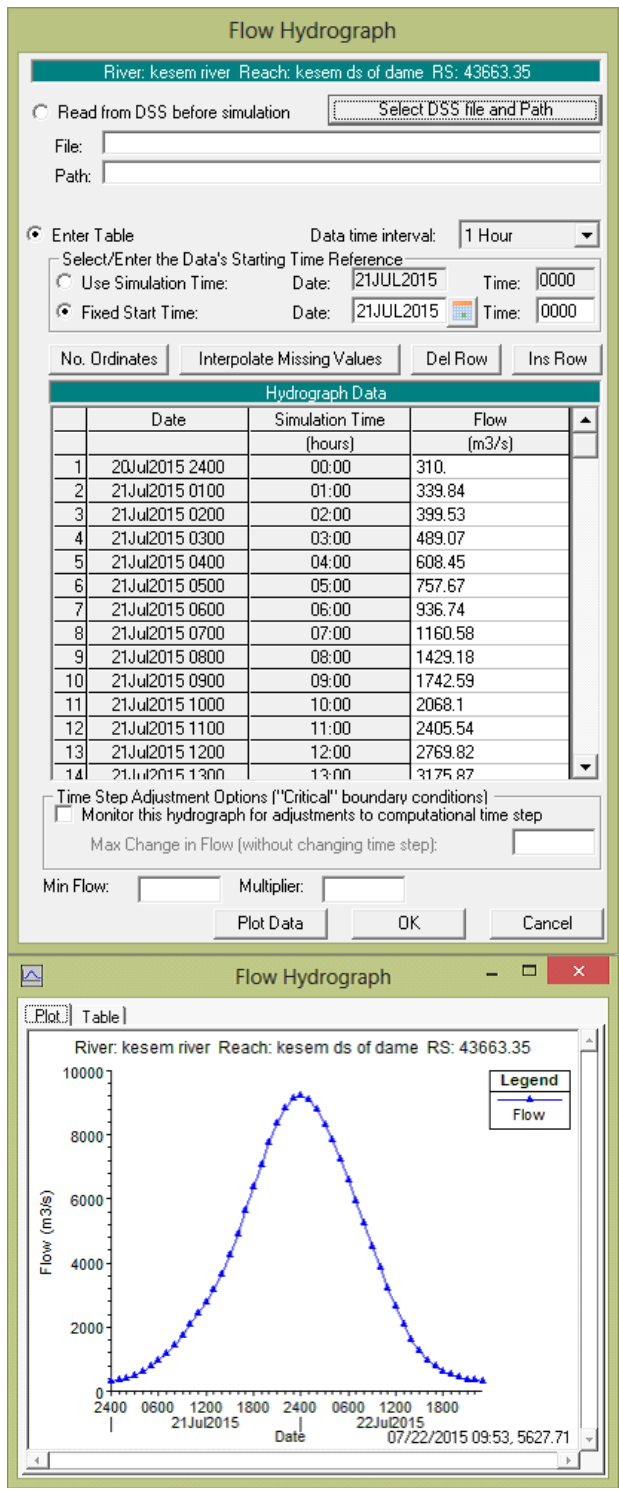

Figure 6. PMF Inflow Hydrograph of Kesem River as an upstream boundary condition in HEC-RAS. 


\subsection{Flood Plain Mapping}

The unsteady flow analysis in HEC-RAS results in water surface elevation at locations from upstream boundary to downstream boundary. This result is used for flood Floodplain mapping which is accomplished in HEC-GeoRAS. The geo-referenced cross sections are imported to HEC-GeoRas and water surface elevations attached to the cross sections are used to create a continuous water surface. The water surface is then compared with the terrain model and the floodplain is identified where the water surface is higher than the terrain. HEC-GeoRAS produces inundation maps for flood extent and depth.

\subsection{Model Protocol}

As it is shown on the chart Figure 7, the first step in dam breach analysis is selection of dam failure Scenario (overtopping, piping, earthquake, land slide etc.). For the selected failure scenario dam breach parameters are determined using the MacDonald and Langridge-Monopolis (1984) and Froehlich (2008) Empirical relationships. On the other hand, HEC-GeoRAS on ArcGIS platform is used to extract river cross section coordinate data at various points along the river by

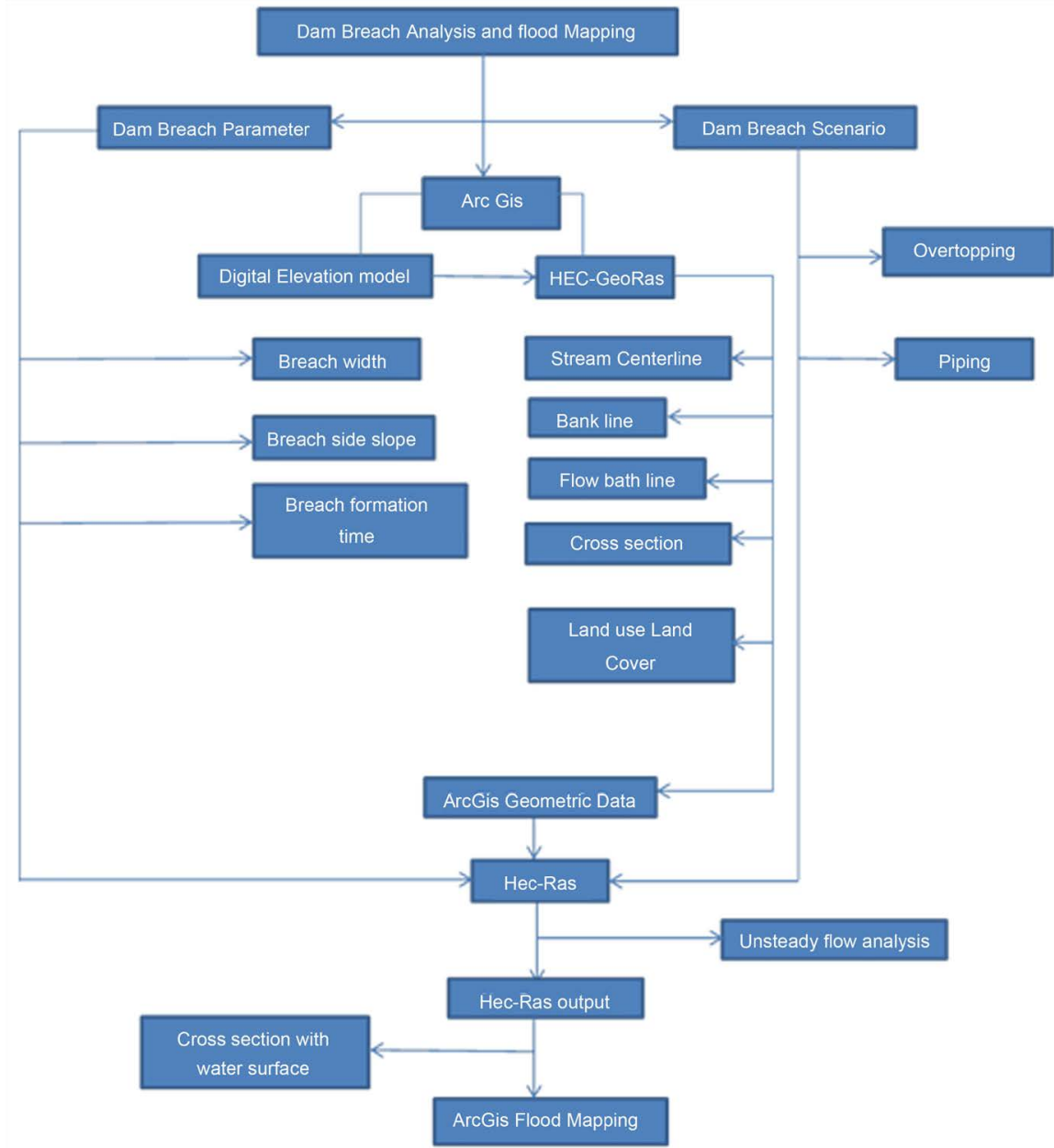

Figure 7. Summary of the methodology of Dam Breach Analysis. 
making use of the digital elevation model of the anticipated flood plain. This extracted coordinates are used to generate geometrical cross sections of river at various points along the river. The cross-sectional data obtained is used for unsteady flow analysis in HEC-RAS. After unsteady flow analysis, the output from HEC-RAS which contains water surface elevations at individual cross-sectional points attached to them; is imported into ArcGIS and is used to prepare a flood map.

\section{Results and Discussion}

Estimating the dam breach parameters is one of the most important things that have to be done before dam breach analysis is simulated. Both MacDonald and Langridge-Monopolis (1984) and Froehlich (2008) are used to estimate breach parameters. The modes of failure for this dam are assumed to be overtopping and piping type of failure.

Breach parameters are estimated for both overtopping and piping and are used as an input for HEC-RAS. These are dam breach parameters breach width, breach side slope and breach formation time which are used as a geometric data during unsteady flow analysis. Results of dam breach parameter calculations for overtopping and piping failure mode for both MacDonald and Langridge-Monopolis (1984) and Froehlich (2008) methods are as follows.

Overtopping: Froehlich (2008):

Average breach width,

$$
\begin{gathered}
B_{\text {avg }}=0.27 K_{o} V_{w}^{0.32} H_{b}^{0.04} \\
B_{\text {avg }}=215.14 \mathrm{~m}
\end{gathered}
$$

Breach formation time,

$$
t_{f}=63.2 \sqrt{\frac{V_{W}}{g H_{b}^{2}}}=1.982 \mathrm{hrs}
$$

Overtopping: MacDonald and Langridge-Monopolis (1984)

Volume of material eroded from the dam embankment,

$$
\begin{gathered}
V_{\text {eroded }}=0.00348\left(V_{\text {out }} * H_{w}\right)^{0.852} \\
V_{\text {eroded }}=3664595.25 \mathrm{~m}^{3}
\end{gathered}
$$

Bottom Width of the breach,

$$
\begin{gathered}
B_{b}=\frac{V_{e r}-H_{b}^{2}\left(C Z_{b}+\frac{H_{b} Z_{b} C_{3}}{3}\right)}{H_{b}\left(C+\frac{H_{b} Z_{3}}{2}\right)} \\
B_{b}=356.13 \mathrm{~m}
\end{gathered}
$$

Breach formation time

$$
\begin{gathered}
t_{f}=0.0178\left(V_{\text {eroded }}\right)^{0.364} \\
t_{f}=4.36 \mathrm{hrs}
\end{gathered}
$$


Piping: Froehlich (2008):

Average breach width,

$$
\begin{gathered}
B_{\text {avg }}=0.27 K_{o} V_{w}^{0.32} H_{b}^{0.04} \\
B_{\text {avg }}=192.93 \mathrm{~m}
\end{gathered}
$$

Breach formation time,

$$
\begin{gathered}
t_{f}=63.2 V_{w} * g H_{b}^{2} \\
t_{f}=1.535 \mathrm{hrs}
\end{gathered}
$$

Piping: MacDonald and Langridge-Monopolis (1984)

Volume of material eroded from the dam embankment,

$$
\begin{gathered}
V_{\text {eroded }}=0.00348\left(V_{\text {out }} * H_{w}\right)^{0.852} \\
V_{\text {eroded }}=2536087.89 \mathrm{~m}^{3}
\end{gathered}
$$

Bottom Width of the breach

$$
\begin{gathered}
B_{b}=\frac{V_{e r}-H_{b}^{2}\left(C Z_{b}+\frac{H_{b} Z_{b} C_{3}}{3}\right)}{H_{b}\left(C+\frac{H_{b} Z_{3}}{2}\right)} \\
B_{b}=148.7 \mathrm{~m}
\end{gathered}
$$

Breach formation time

$$
\begin{gathered}
t_{f}=0.0178\left(V_{\text {eroded }}\right)^{0.364} \\
t_{f}=3.81 \mathrm{hrs}
\end{gathered}
$$

Summary of dam breach parameters using Macdonald and Langridge-Monopolis and Froehlich's method is presented in Table 3 for Kesem-Kebena Dam.

Breach parameter from one of the methods is selected Based on the results from unsteady flow analysis, envelop curve and peak outflow regression equations.

Table 3. Summary of estimated breach parameters.

\begin{tabular}{ccc}
\hline & Table Overtopping & \\
\hline Dam breach parameters & Froehlich (2008) & $\begin{array}{c}\text { Macdonald and Langridge- } \\
\text { Monopolis (1984) }\end{array}$ \\
\hline Breach bottom width & $215.14 \mathrm{~m}$ & $356.13 \mathrm{~m}$ \\
Breach side slope & $1.0: 1$ & $0.5: 1$ \\
Breach formation time & $1.982 \mathrm{hrs}$ & $4.36 \mathrm{hrs}$ \\
Breach bottom width & Piping & $148.7 \mathrm{~m}$ \\
Breach side slope & $136.95 \mathrm{~m}$ & $0.5: 1$ \\
Breach formation time & $0.7: 1$ & $3.81 \mathrm{hrs}$
\end{tabular}




\subsection{Unsteady Flow Analysis}

Unsteady flow analysis is the basic part of dam breach analysis where PMF flood hydrograph entering in to the reservoir is routed as it passes through the reservoir to the crest of the dam or the breach section. Further routing is also done as the flood wave travels to the downstream boundary section of the river. Area elevation curve has been developed and used for reservoir routing (Appendix 2), whereas channel geometry obtained from Hec-GeoRas was used for channel routing. After entering initial conditions and boundary conditions for the farthest upstream and downstream cross sections in to HEC-RAS; unsteady flow simulation can be initiated. In the unsteady flow analysis of this study; PMF inflow hydrograph of Kesem River and normal depth of the farthest downstream vicinity are used as a boundary condition whereas, initial flow and elevation for the storage area are used as initial conditions.

\section{Unsteady flow analysis of overtopping}

Unsteady flow simulation of overtopping failure in HEC-RAS requires PMF inflow hydrograph as an upstream boundary condition. Overtopping failure occurs when the flood due to the PMF inflow passes over the embankment.

Flood resulting from the PMF of Kesem River did not overtop the dam during unsteady flow simulation. The PMF raised the reservoir water surface elevation only to $939 \mathrm{~m}$ which is $2 \mathrm{~m}$ below the dam crest. Figure 8 shows the maximum water surface elevation on the dam profile during unsteady flow simulation.

\subsection{Unsteady Flow Analysis of Piping}

Unsteady flow analysis due to piping of Kesem dam in HEC-RAS is done after entering the necessary data for the simulation to begin. Dam breach parameters and boundary conditions in this case are the necessary data that are used as an

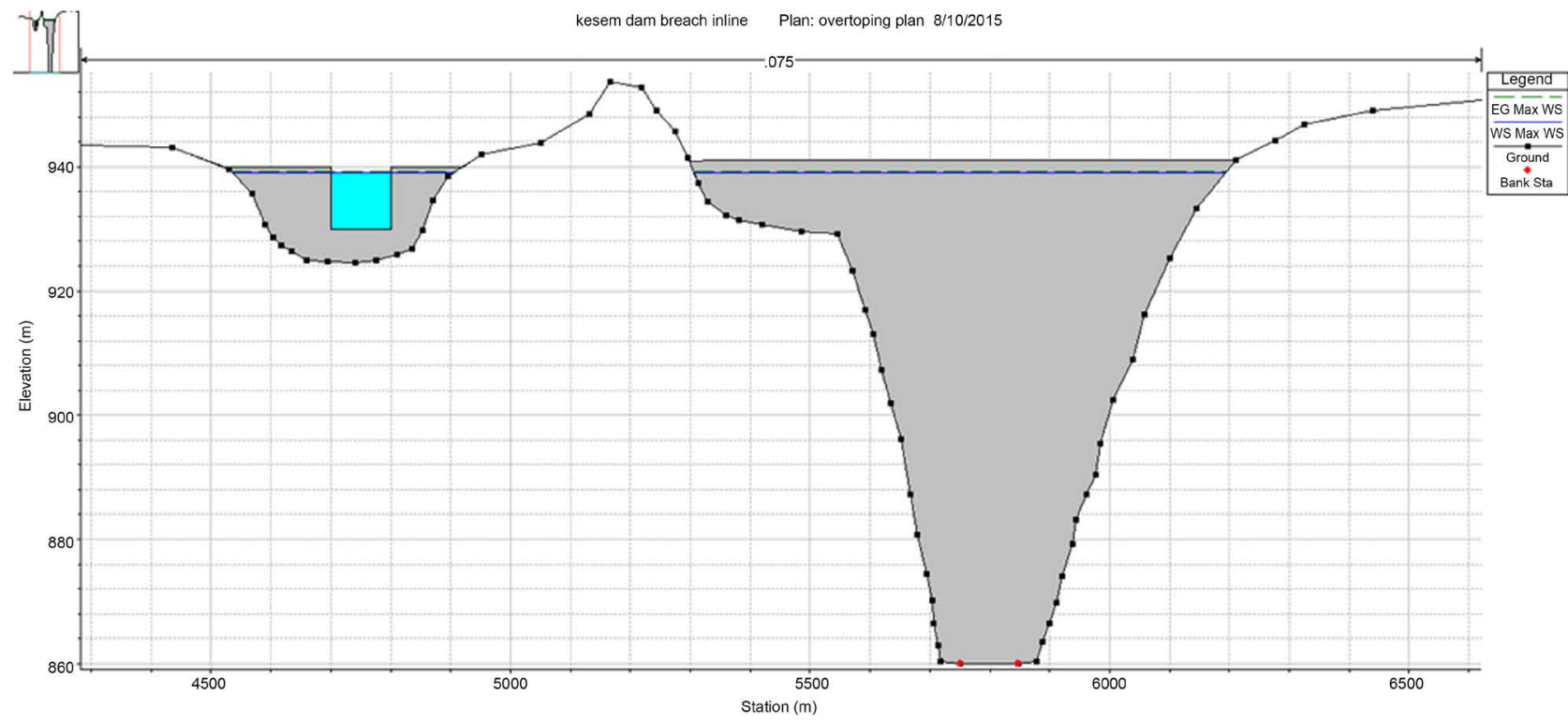

Figure 8. Kesem Dam with maximum water surface. 
input in to HEC-RAS. For comparison two empirical formulas MacDonald and Langridge-Monopolis (1984) and Froehlich (2008) are used to estimate breach parameters. Unsteady flow analysis of piping in HEC-RAS is done for both methods.

The starting water surface elevation for piping is taken at the crest of the spillway, since the spill way is only used during flood events. Figure 9 shows water surface elevation before piping begins.

Using breach parameters from Froehlich (2008) and MacDonald and Langridge-Monopolis (1984) for unsteady flow analysis in HEC-RAS out flow hydrograph from the breached dam and hydrograph at every cross section are obtained after the unsteady flow simulation. Figure 10 and Figure 11 shows hydrographs at the inline structure and at $20 \mathrm{~km}, 40 \mathrm{~km}$ and $60 \mathrm{~km}$ from the dam for both Froehlich (2008) and MacDonald and Langridge-Monopolis (1984) respectively.

Both Froehlich (2008) and MacDonald and Langridge-Monopolis (1984) have their own importance, Froehlich (2008) differentiate between piping and overtopping and MacDonald and Langridge-Monopolis (1984) differentiate between earth fill dam and rock fill dam. Breach parameters from both equations are more or less similar but breach formation time which is one of the parameters is $1.535 \mathrm{hrs}$ for Froehlich (2008) and $3.81 \mathrm{hrs}$ for MacDonald and Langridge-Monopolis (1984). This makes the magnitude of the pick outflow diminish and the out flow flood to take longer time to pass through the breach in case of MacDonald and Langridge-Monopolis (1984). Figure 12 shows the difference between breach out flow hydrographs using Froehlich (2008) and MacDonald and Langridge-Monopolis (1984).

After unsteady flow analysis due to piping is simulated in HEC-RAS, The result can show the breach on the inline structure and water surface profile of Kesem

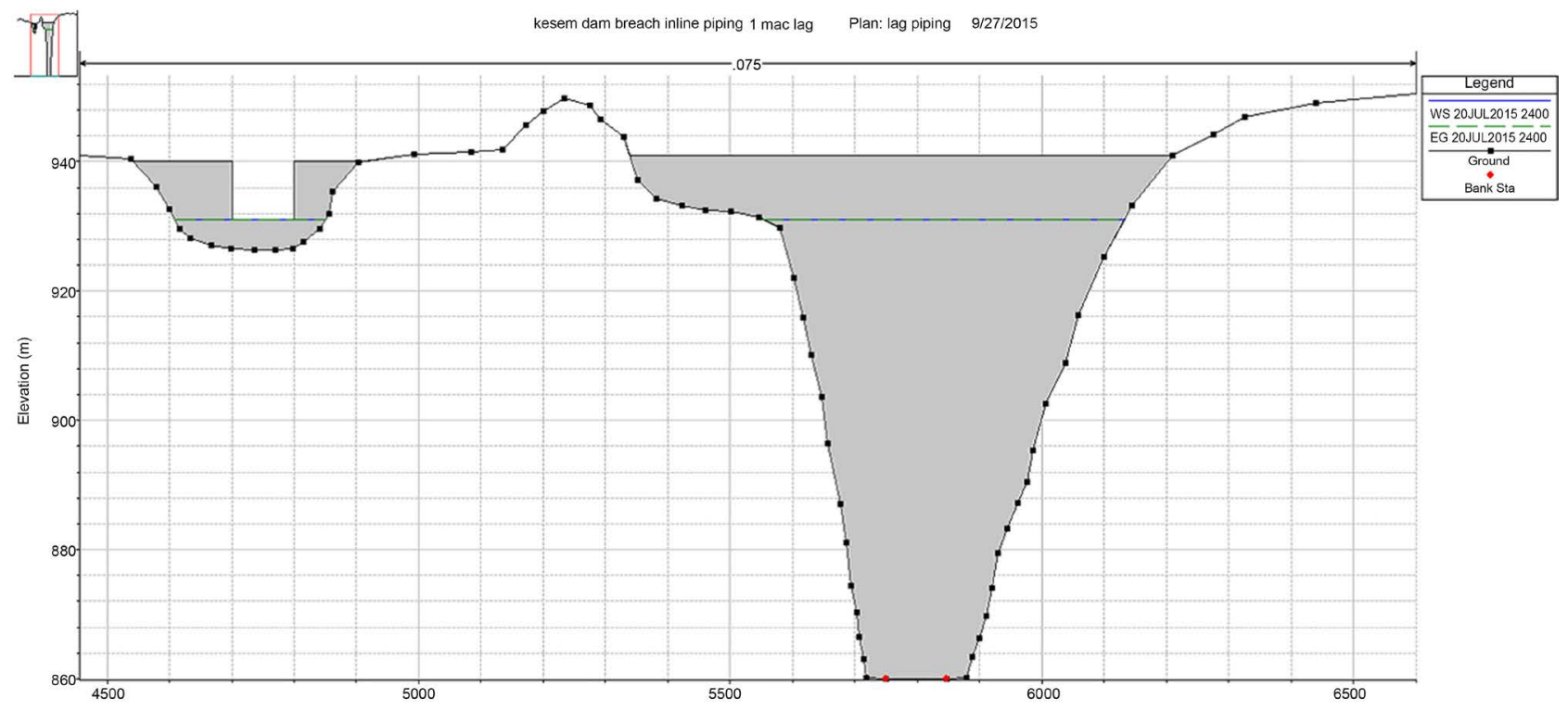

Figure 9. Kesem dam profile with water surface profile at the spillway crust level. 


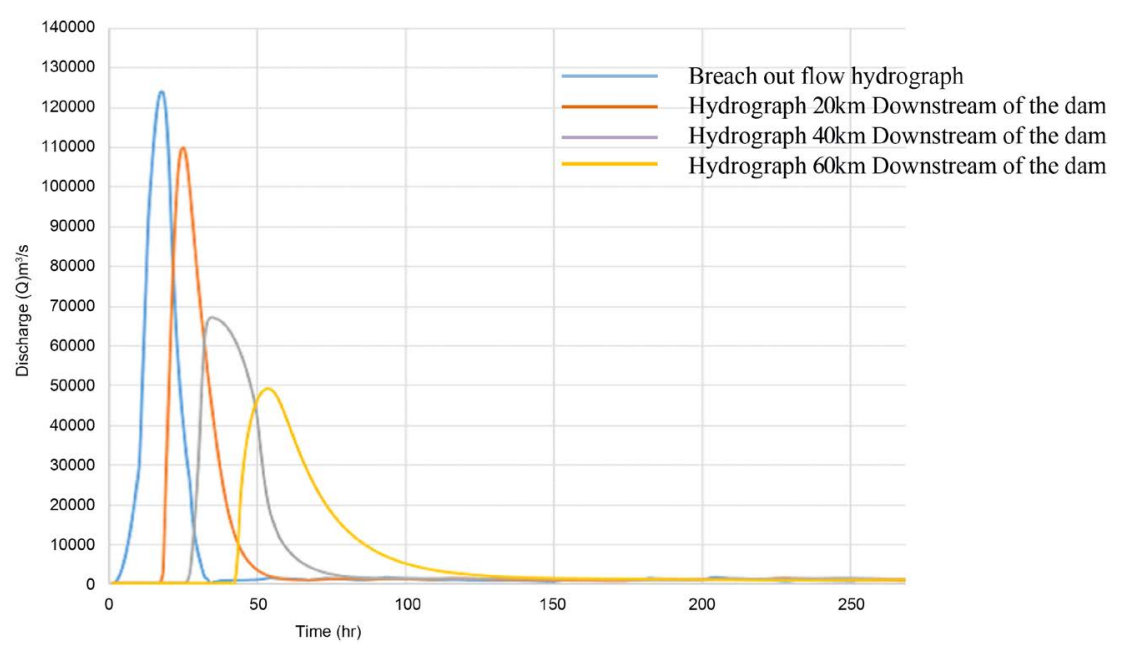

Figure 10. Hydrographs after unsteady flow analysis using Froehlich (2008).

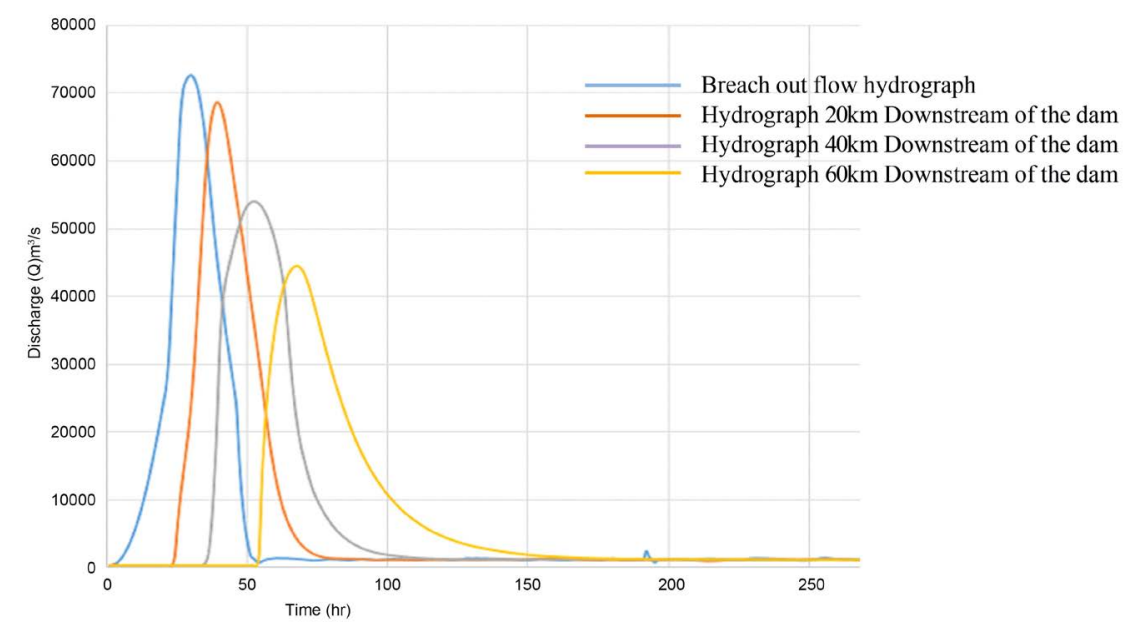

Figure 11. Hydrographs after unsteady flow analysis using MacDonald and LangridgeMonopolis (1984).

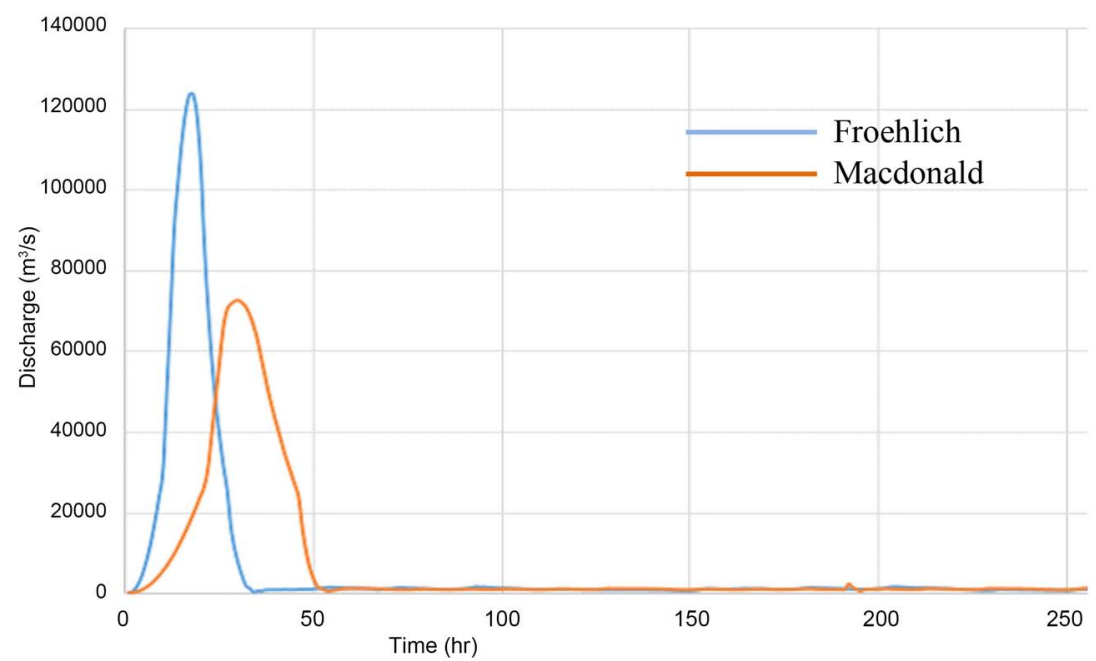

Figure 12. Breach out flow hydrograph of Froehlich (2008) and MacDonald and Langridge-Monopolis (1984). 
River. Figure 13 and Figure 14 shows breach on Kesem dam and water surface profile of Kesem River.

\subsection{Peak Flow Equations and Envelop Curve}

The computed peak outflow from the HEC-RAS model for both Froehlich (2008) $\left(Q_{p}=123,685.8 \mathrm{~m}^{3} / \mathrm{s}\right)$ and MacDonald and Langridge Monopolis (1984) $\left(Q_{p}=\right.$ $72,670.8 \mathrm{~m}^{3} / \mathrm{s}$ ) are compered to Peak outflow regression equations as a test for reasonableness. Several researchers have developed equations from historical dam failure data. The equations developed are only used for comparison purpose.

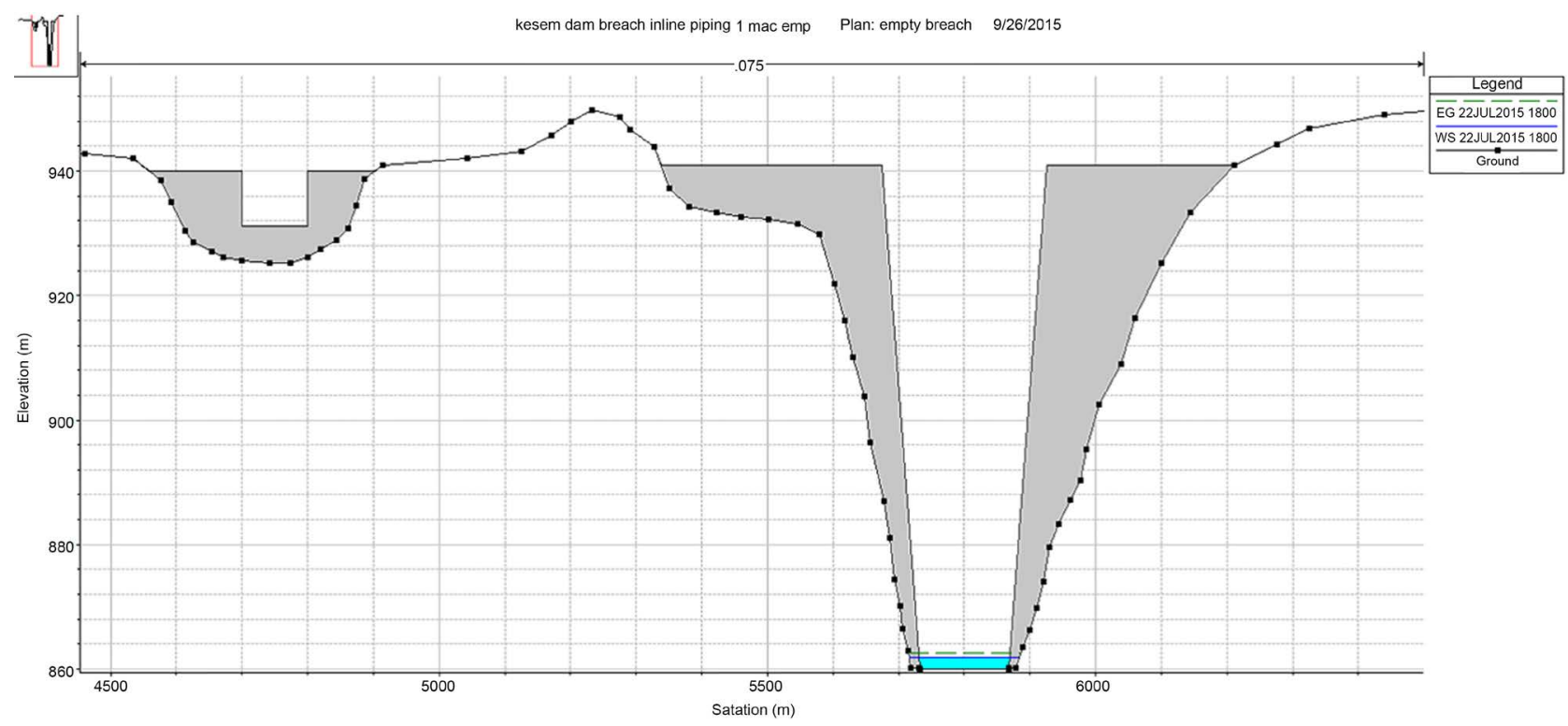

Figure 13. Kesem dam profile after the breach.

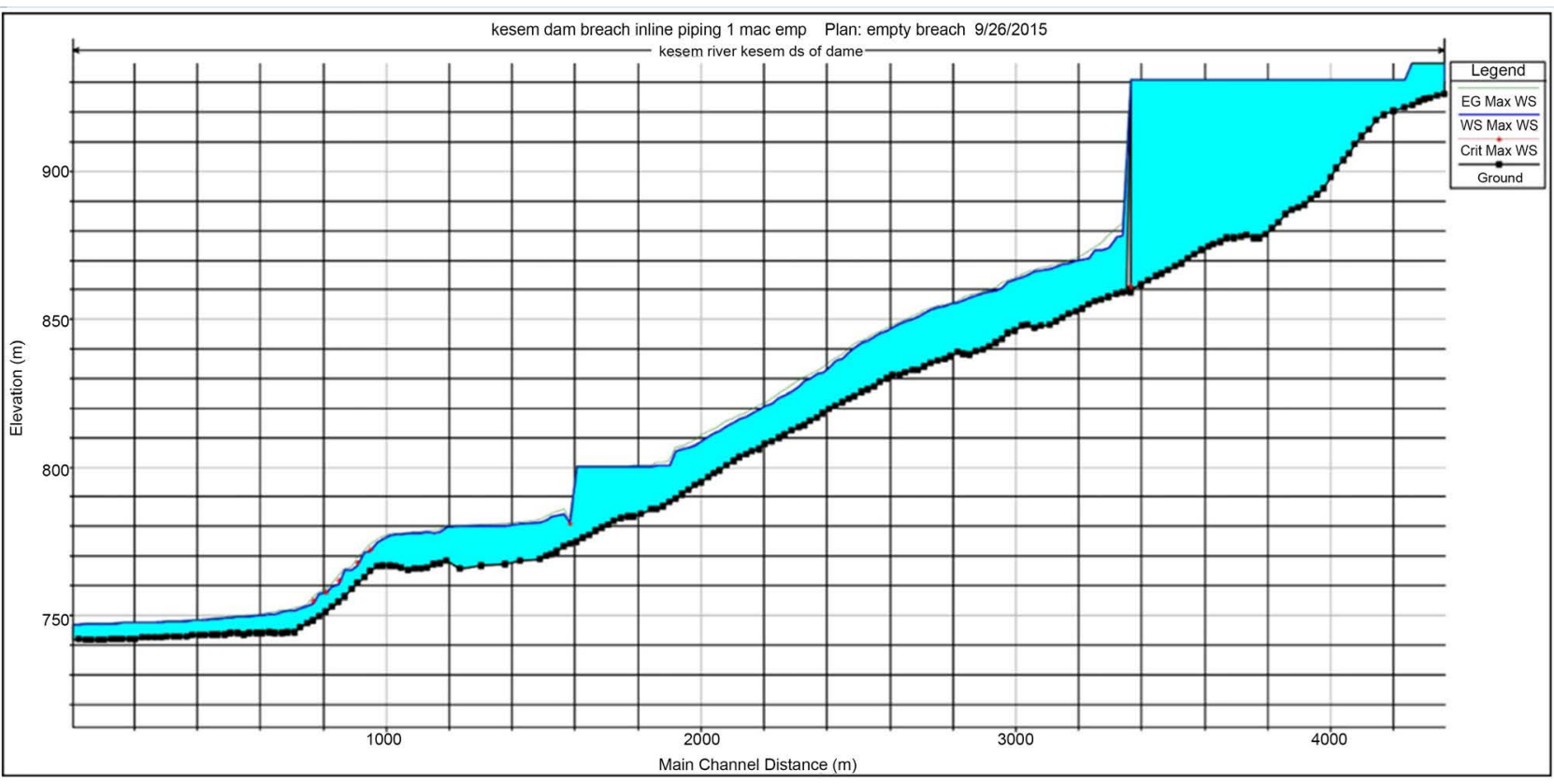

Figure 14. Water surface profile of Kesem River. 
Shown below is peak outflow equations and there resulting peak outflow for Kesem dam breach.

- $\operatorname{USBR}(1982): Q=19.1\left(h_{w}\right)^{1.85}=49483 \mathrm{~m}^{3}$ $h_{w}$-Depth of water above the breach invert at time of breach $(70 \mathrm{~m})$

- MacDonald and Langridge Monopolis (1984): $Q=3.85\left(V_{w} h_{w}\right)^{0.411}=81618.04 \mathrm{~m}^{3}$

$V_{w}$-volume of water above the breach invert $\left(480 \mathrm{Mm}^{3}\right)$

- Soil conservation service (SCS, 1981): $Q=16.6\left(h_{w}\right)^{1.85}=43007.03 \mathrm{~m}^{3}$

- Hagen (1982): $Q=0.54\left(S h_{d}\right)^{0.5}=106477.265 \mathrm{~m}^{3}$

$S$-Reservoir storage for water surface elevation at breach time $\left(480 \mathrm{M}^{3}\right)$

$h_{d}$-height of the dam $(81 \mathrm{~m})$

- Singh and Snorrason (1984): $Q=13.4\left(h_{d}\right)^{1.89}=54217.794 \mathrm{~m}^{3}$

- Costa (1985): $Q=1.122(S)^{0.57}=99609.41 \mathrm{~m}^{3}$

Peak outflow obtained from the HEC-RAS model using breach parameters from Macdonald and Langridge Monopolis (1984) is closer to peak outflow from regression equations when compared to peak outflow Obtained from the model using breach parameters from Froehlich (2008). Peak outflow from the model using breach parameters from Macdonald and Langridge Monopolis (1984) have an average error of 0.3 when compared with results from peak outflow regression equations whereas peak outflow from the model using breach parameters from Froehlich (2008) have an average error of 0.4 when compared with results from peak outflow regression equations.

Froehlich (2008) $Q_{p}-4,271,521.367 \mathrm{cfs}\left(120,000 \mathrm{~m}^{3} / \mathrm{s}\right)$.

Macdonald and Langridge Monopolis (1984) $Q_{p}-2,272,026.669$ cfs $(74,000$ $\left.\mathrm{m}^{3} / \mathrm{s}\right)$.

Hydraulic Depth $230 \mathrm{ft}$.

In addition to the peak flow equations, the model peak outflow can also be compared to envelop curve of historical failure. Figure 15 shows the envelop curve and where peak outflows from the model lay on the envelop curve; while using breach parameters from both Macdonald and Langridge Monopolis (1984) and Froehlich (2008).

Peak outflow obtained from the HEC-RAS model using breach parameters from Macdonald and Langridge Monopolis (1984) lays in the envelop curve but peak outflow obtained from HEC-RAS using breach parameters from Froehlich (2008) lays outside of the curve. This shows that breach parameters obtained from Macdonald and Langridge Monopolis (1984) is more conservative than breach parameters obtained from Froehlich (2008) therefore it is selected for analysis. Breach outflow hydrograph has been presented in Appendix 3.

\subsection{Flood Mapping}

Flood mapping is the final step in dam breach analysis. In this study, the HEC-GeoRAS tool in GIS performs the flood mapping process in GIS. The flood map shows the maximum water surface and up to where this maximum water 


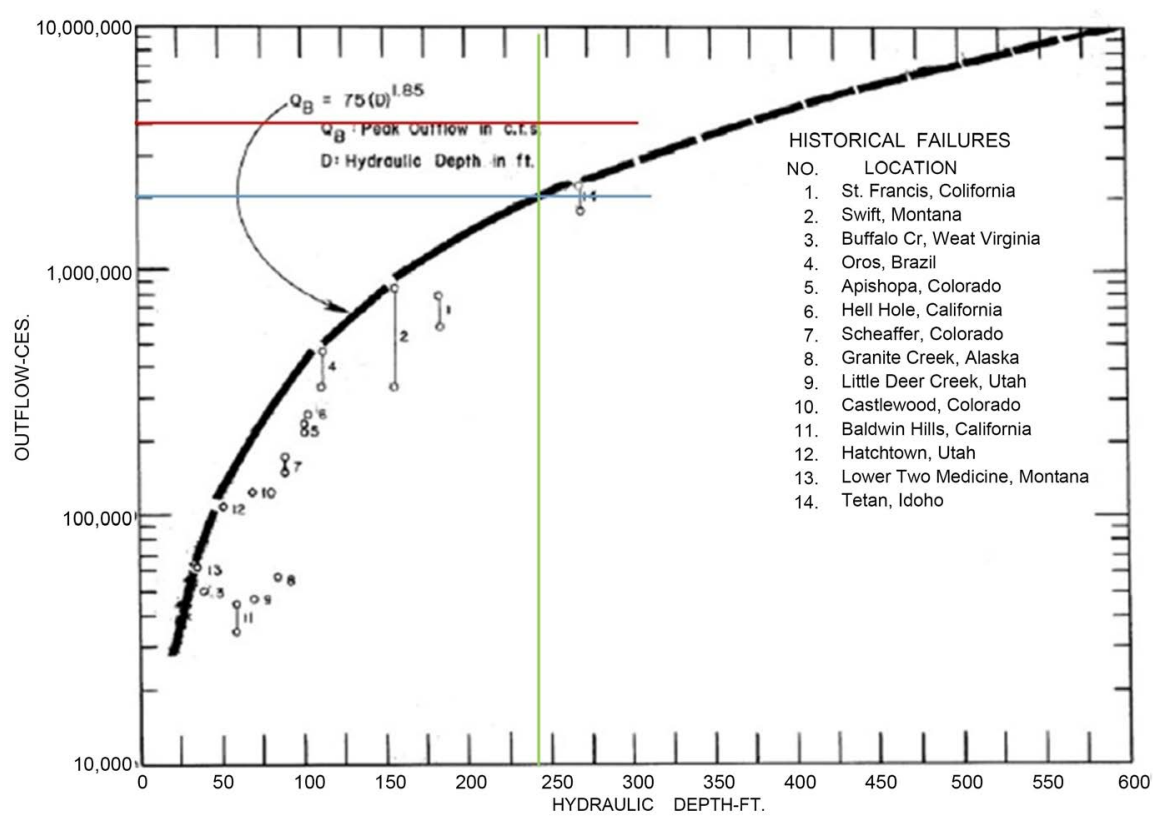

Figure 15. Peak outflow envelop curve of Historical dam failures.

surface extends on the flood plain. The flood map is created on a type of DEM called TIN which is derived from a raster DEM. Once the flood map is created it can be shown on the TIN itself or on an aerial map of the study area. Since peak outflow from HEC-RAS using breach parameters from Macdonald and Langridge Monopolis (1984) is more accurate when compared with results of peak outflow regression equations and lays inside the envelop curve, water surface elevations obtained using breach parameters from Macdonald and Langridge Monopolis (1984) are used for the mapping process. Figure 16 shows map of the flood due to piping of Kesem Dam on a TIN and Figure 17 shows map of flood due to piping of Kesem dam on an aerial map.

The flood map covers $183 \mathrm{~km}^{2}$ of land which is under water. The map shows different water surface elevations, differentiating them with color.

As seen from the flood map that is overlain on areal map of the study area Sabure Town and Alibete village are affected by the flood.

The water surface profile can also be displayed on the XYZ perspective plot in HEC-RAS. Figure 18 shows the XYZ perspective plot for unsteady flow analysis of Kesem River.

\section{Conclusions and Recommendation}

\subsection{Conclusions}

Dam breach is modeled after selecting a failure scenario. Failure scenarios selected for this study are overtopping and piping, because most historical dam failures are due to those types of failure scenario. In this study, Kesem dam can safely pass the PMF inflow of Kesem River without overtopping the embankment; this is because the dam has adequate spillway capacity and free board. 


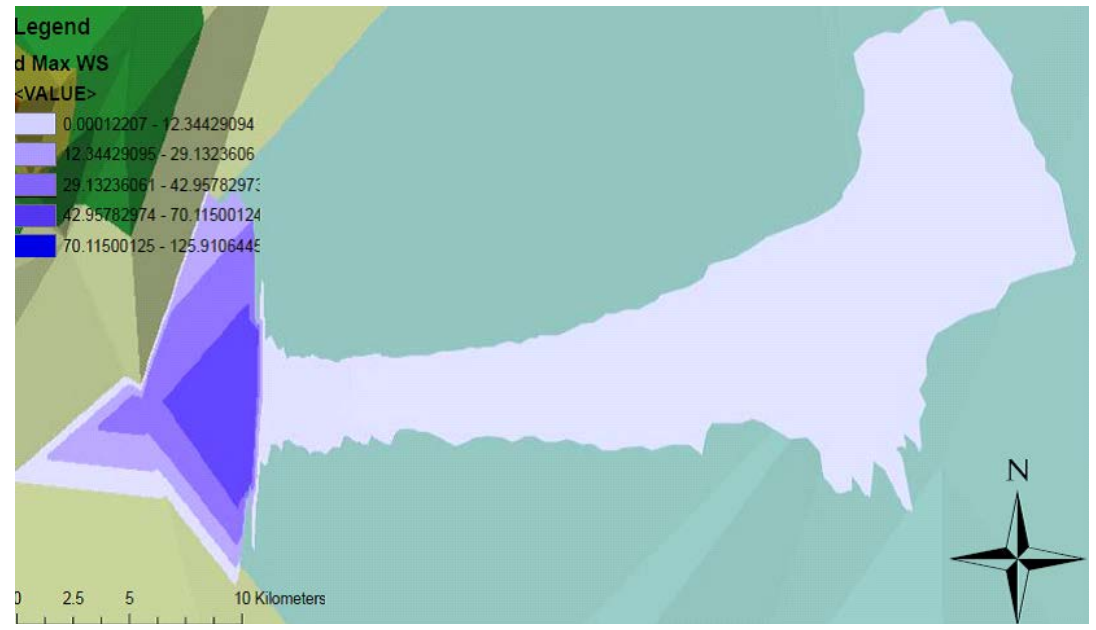

Figure 16. Flood map on a TIN derived from DEM.

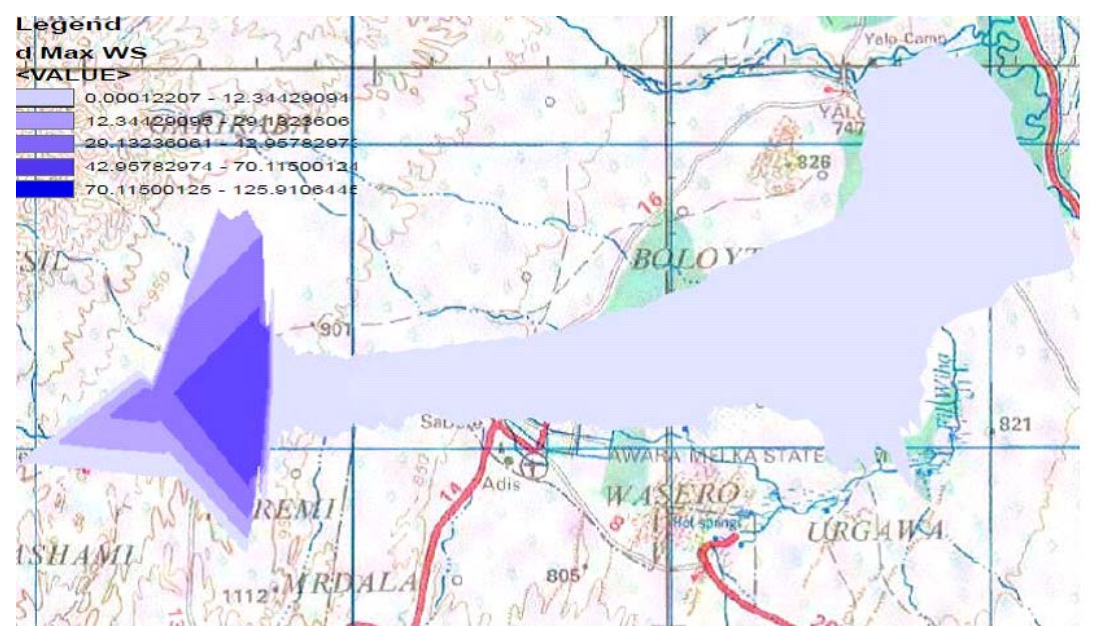

Figure 17. Flood map on an aerial map of the study area.

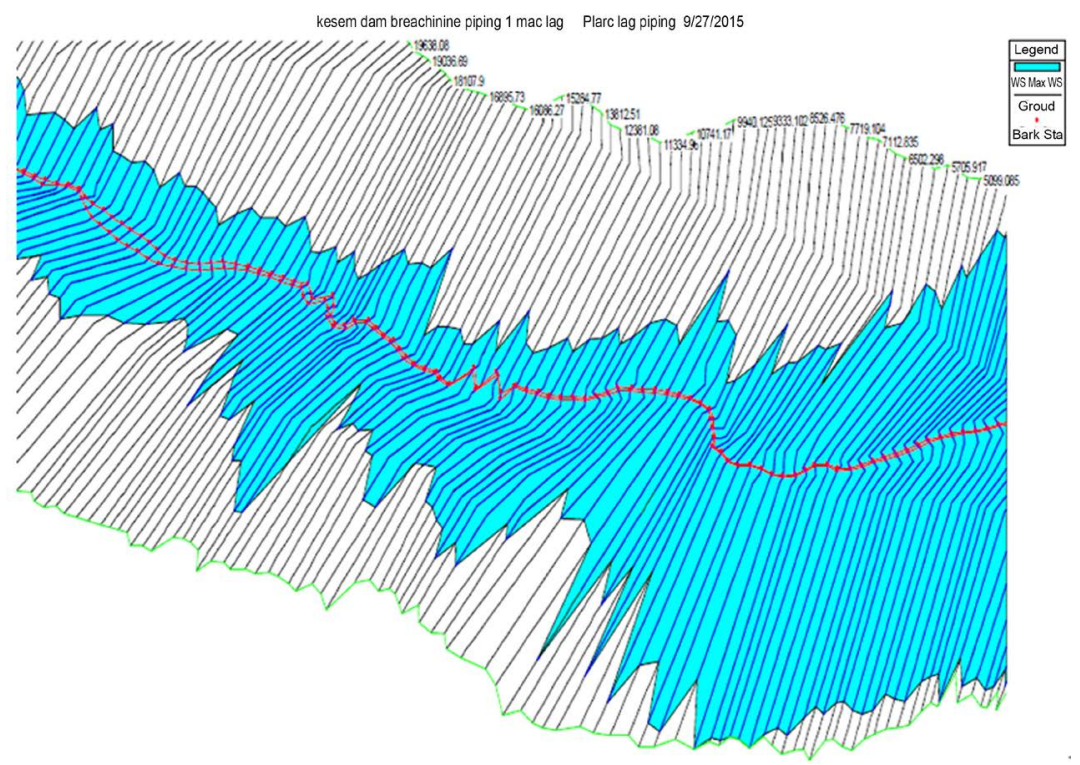

Figure 18. Perspective plot of water surface profile in HEC-RAS. 
Empirical formulas are used to predict the breach parameters of Kesem dam. Froehlich (2008) and MacDonald and Langridge-Monopolis (1984) are used to estimate the breach parameter, where in turn the breach parameters are used for unsteady flow calculations in HEC-RAS. When peak outflow obtained with this empirical equations were compared to peak outflow empirical equations and peak out flow envelop curve from historical dam failure, MacDonald and Langridge-Monopolis (1984) was found to be more conservative and reliable as can be seen in the result. Peak outflow obtained using MacDonald and LangridgeMonopolis (1984) have an error of 0.3 when compared to peak outflow equations and lays inside the peak outflow envelop curve. Peak outflow obtained using Froehlich (2008) have an error of 0.4 when compared to peak outflow empirical equations from historical failure and lays outside the peak outflow envelop curve. Hence, Peak outflow using MacDonald and Langridge-Monopolis (1984) was chosen for unsteady flow analysis in HEC-RAS and Inundation Mapping in ArcGIS.

From the plotted flood map on ARCGIS TIN and aerial map, it can be seen that the flood affects 18,300 hectares of area. The XYZ plot also shows the extent of the water surface on the cross sections. The XYZ perspective plot in HECRAS and the flood map on ARCGIS are somewhat different, this is because HEC-RAS only sees elevation deferens on the cross sections not in between the cross sections but it is a different case for ARCGIS it can see elevation difference everywhere depending on the quality of DEM. From the map, it can be concluded the flood from the dam breach covers Sabure town, Alibete village and irrigation farms.

\subsection{Recommendation}

Although there are number of dams for hydropower, irrigation and water supply in Ethiopia, dam breach analysis has been given very little and/or no attention in the country. But it is very essential towards mitigating loss of life and property due to the flood from the dam breach. In the future, more studies on dam breach analysis will need be done in this country. Possible infrastructural developments in the towns affected by flooding during the event of dam breach, needs to account for possible emergency conditions. This may include adequate water ways for construction of bridges. Emergency drills might also need to be prepared for these conditions by the concerned flood management and mitigation offices.

\section{Conflicts of Interest}

The authors declare no conflicts of interest regarding the publication of this paper.

\section{References}

[1] MOWR (2007) Kesem-Kebena Dam and Irrigation Project Dam and Appurtenant Works Final Design Report.

[2] Gee, D.M. (2009) Comparison of Dam Breach Parameter Estimators. World Envi- 
ronmental and Water Resources Congress, Kansas City, 17-21 May 2009. https://doi.org/10.1061/41036(342)339

[3] Sanjay, D. and Chauhan, S.S. (2005) Do Current Breach Parameters Estimation Techniques Provide Reasonable Estimates for Use in Breach Modeling? The College of Information Science and Technology, The Pennsylvania State University, State College.

[4] Federal Energy Regulatory Commission Division of Dam Sefty and Inspections (1987) Guidelines for Drilling in and near Embankment Dams and Their Foundations.

[5] Fread, D. (1988) Breach: An Erosion Model for Earthen Dam Failures.

[6] Singh, V.P. (1988) Dimensional Analytical Solutions for Dam-Breach Erosion.

[7] HEC (2005) HEC-GeoRAS User's Manual: An Extension for Support of HEC-RAS Using ArcGIS. US Army Corps of Engineering Hydrologic Engineering Center, Davis.

[8] HEC (2010) HEC-RAS River Analysis System User Manual. US Army Corps of Engineers Institute for Water Resource Hydrologic Engineering Center (HEC), Davis.

[9] Cameron, P.A. and Ackerman, T. (2008) Dam Failure Analysis Using HEC-RAS and HEC-GeoRas. Hydraulic Engineer and Senior Technical Hydraulic Engineer, Hydrologic Engineering Center, Davis.

[10] Merwade, V. (2012) HEC-GeoRAS with ArcGIS 10 and HEC-RAS Modelng. Purdue University, School of Civil Engineering, West Lafayette.

[11] Chow, V.T. (1960) Open Channel Hydraulics. McGraw-Hill, New York. 


\section{Appendix 1}

\section{PMF inflow hydrograph of the entire catchment}

\begin{tabular}{|c|c|c|}
\hline Direct surface runoff Hydrograph & Base Flow & PMF Hydrograph \\
\hline$\left(\mathrm{m}^{3} / \mathrm{s}\right)$ & $\left(\mathrm{m}^{3} / \mathrm{s}\right)$ & $\left(\mathrm{m}^{3} / \mathrm{s}\right)$ \\
\hline 0 & 310 & 310 \\
\hline 29.8448 & 310 & 339.8448 \\
\hline 89.5344 & 310 & 399.5344 \\
\hline 179.0688 & 310 & 489.0688 \\
\hline 298.448 & 310 & 608.448 \\
\hline 447.672 & 310 & 757.672 \\
\hline 626.7408 & 310 & 936.7408 \\
\hline 850.5768 & 310 & 1160.5768 \\
\hline 1119.18 & 310 & 1429.18 \\
\hline 1432.5872 & 310 & 1742.5872 \\
\hline 1758.1016 & 310 & 2068.1016 \\
\hline 2095.5392 & 310 & 2405.5392 \\
\hline 2459.8224 & 310 & 2769.8224 \\
\hline 2865.8736 & 310 & 3175.8736 \\
\hline 3343.5376 & 310 & 3653.5376 \\
\hline 3922.6776 & 310 & 4232.6776 \\
\hline 4594.4064 & 310 & 4904.4064 \\
\hline 5328.7872 & 310 & 5638.7872 \\
\hline 6066.1488 & 310 & 6376.1488 \\
\hline 6767.7592 & 310 & 7077.7592 \\
\hline 7433.5448 & 310 & 7743.5448 \\
\hline 8024.792 & 310 & 8334.792 \\
\hline 8502.7136 & 310 & 8812.7136 \\
\hline 8819.6352 & 310 & 9129.6352 \\
\hline 8927.772 & 310 & 9237.772 \\
\hline 8791.1704 & 310 & 9101.1704 \\
\hline 8457.284 & 310 & 8767.284 \\
\hline 8021.5168 & 310 & 8331.5168 \\
\hline 7508.0464 & 310 & 7818.0464 \\
\hline 6916.9464 & 310 & 7226.9464 \\
\hline 6272.008 & 310 & 6582.008 \\
\hline 5606.0936 & 310 & 5916.0936 \\
\hline 4919.2952 & 310 & 5229.2952 \\
\hline 4211.576 & 310 & 4521.576 \\
\hline
\end{tabular}


Continued

\begin{tabular}{ccc}
\hline 3539.516 & 310 & 3849.516 \\
2903.2992 & 310 & 3213.2992 \\
2311.8864 & 310 & 2621.8864 \\
1774.2384 & 310 & 2084.2384 \\
1308.2768 & 310 & 1618.2768 \\
931.9232 & 310 & 1241.9232 \\
654.1384 & 310 & 964.1384 \\
457.0008 & 310 & 767.0008 \\
304.6672 & 310 & 614.6672 \\
188.1768 & 310 & 498.1768 \\
107.5296 & 310 & 417.5296 \\
53.7648 & 310 & 363.7648 \\
17.9216 & 310 & 327.9216 \\
0 & 310 & 310 \\
\hline
\end{tabular}

\section{Appendix 2}

Elevation, area and capacity relationship of Kesem Reservoir

\begin{tabular}{|c|c|c|}
\hline Elevation & Original Area & Original Capacity \\
\hline$(\mathrm{m})$ & $\left(\mathrm{km}^{2}\right)$ & $(\mathrm{MCM})$ \\
\hline 930 & 28.66 & 480 \\
\hline 928 & 26.38 & 410 \\
\hline 926 & 24.5 & 365 \\
\hline 924 & 21.29 & 324 \\
\hline 922 & 19 & 285 \\
\hline 920 & 16.5 & 248 \\
\hline 918 & 13.86 & 216 \\
\hline 916 & 12.7 & 190 \\
\hline 914 & 11.29 & 165 \\
\hline 912 & 10.1 & 143 \\
\hline 910 & 9.45 & 124.7 \\
\hline 909 & 8.9 & 113.6 \\
\hline 908 & 8.34 & 103 \\
\hline 906 & 7.76 & 89 \\
\hline 904 & 6.73 & 74.68 \\
\hline 902 & 5.68 & 61.8 \\
\hline 900 & 5.1 & 52 \\
\hline 898 & 4.18 & 40.4 \\
\hline
\end{tabular}




\section{Continued}

\begin{tabular}{|c|c|c|}
\hline 896 & 3.78 & 35.72 \\
\hline 894 & 2.98 & 27.26 \\
\hline 892 & 2.29 & 20.67 \\
\hline 890 & 2 & 17.8 \\
\hline 888 & 1.62 & 13.3 \\
\hline 886 & 1.38 & 11.56 \\
\hline 884 & 1.06 & 8.51 \\
\hline 882 & 0.84 & 6.13 \\
\hline 880 & 0.68 & 5.1 \\
\hline 878 & 0.5 & 3.6 \\
\hline 876 & 0.42 & 3.07 \\
\hline 874 & 0.32 & 2.4 \\
\hline 872 & 0.28 & 2 \\
\hline 870 & 0.22 & 1.7 \\
\hline 868 & 0.18 & 1.4 \\
\hline 866 & 0.14 & 0.9 \\
\hline 864 & 0.09 & 0.5 \\
\hline 862 & 0.05 & 0.2 \\
\hline 860 & 0 & 0 \\
\hline
\end{tabular}

\section{Appendix 3}

Breach outflow hydrograph using Dam breach parameters from Macdonald and Langridge-Monopolis

\begin{tabular}{|c|c|c|c|}
\hline \multicolumn{4}{|c|}{ River: kesem river Reach: kesem ds of dame RS: 33702.87} \\
\hline & & Stage & Flow \\
\hline & \multirow[t]{2}{*}{ Date } & INST-VAL & INST-VAL \\
\hline & & METERS & $\mathrm{M} 3 / \mathrm{S}$ \\
\hline 1 & $20 \mathrm{Jul} 20152400$ & 931.11 & 310.38 \\
\hline 2 & $21 \mathrm{Jul} 20150005$ & 931.1 & 374.29 \\
\hline 3 & $21 \mathrm{Jul} 20150010$ & 931.1 & 578.74 \\
\hline 4 & $21 \mathrm{Jul} 20150015$ & 930.96 & 869.59 \\
\hline 5 & $21 \mathrm{Jul} 20150020$ & 930.94 & 1356.96 \\
\hline 6 & $21 \mathrm{Jul} 20150025$ & 930.91 & 1976.62 \\
\hline 7 & $21 \mathrm{Jul} 20150030$ & 930.8 & 2710.48 \\
\hline 8 & $21 \mathrm{Jul} 20150035$ & 930.72 & 3596.91 \\
\hline 9 & $21 \mathrm{Jul} 20150040$ & 930.63 & 4621.29 \\
\hline 10 & $21 \mathrm{Jul} 20150045$ & 930.51 & 5775.41 \\
\hline
\end{tabular}




\section{Continued}

\begin{tabular}{|c|c|c|c|}
\hline 11 & $21 \mathrm{Jul} 20150050$ & 930.37 & 7062.89 \\
\hline 12 & $21 \mathrm{Jul} 20150055$ & 930.22 & 8489.24 \\
\hline 13 & $21 \mathrm{Jul} 20150100$ & 930.05 & 10052.16 \\
\hline 14 & $21 \mathrm{Jul} 20150105$ & 929.84 & 11761.06 \\
\hline 15 & $21 \mathrm{Jul} 20150110$ & 929.62 & 13597.78 \\
\hline 16 & $21 \mathrm{Jul} 20150115$ & 929.38 & 15555.28 \\
\hline 17 & $21 \mathrm{Jul} 20150120$ & 929.11 & 17626.51 \\
\hline 18 & $21 \mathrm{Jul} 20150125$ & 928.79 & 19799.97 \\
\hline 19 & $21 \mathrm{Jul} 20150130$ & 928.43 & 22069.26 \\
\hline 20 & $21 \mathrm{Jul} 20150135$ & 928.03 & 24426.03 \\
\hline 21 & $21 \mathrm{Jul} 20150140$ & 927.56 & 26855.79 \\
\hline 22 & $21 \mathrm{Jul} 20150145$ & 926.94 & 31987.12 \\
\hline 23 & $21 \mathrm{Jul} 20150150$ & 926.15 & 40679.11 \\
\hline 24 & $21 \mathrm{Jul} 20150155$ & 925.18 & 49383.71 \\
\hline 25 & $21 \mathrm{Jul} 20150200$ & 923.94 & 58048.04 \\
\hline 26 & $21 \mathrm{Jul} 20150205$ & 922.39 & 66360.09 \\
\hline 27 & $21 \mathrm{Jul} 20150210$ & 920.77 & 70518.41 \\
\hline 28 & $21 \mathrm{Jul} 20150215$ & 919 & 71827.07 \\
\hline 29 & $21 \mathrm{Jul} 20150220$ & 917.05 & 72507.2 \\
\hline 30 & $21 \mathrm{Jul} 20150225$ & 914.98 & 72670.8 \\
\hline 31 & $21 \mathrm{Jul} 20150230$ & 912.69 & 72060.66 \\
\hline 32 & $21 \mathrm{Jul} 20150235$ & 910.31 & 70956.92 \\
\hline 33 & $21 \mathrm{Jul} 20150240$ & 907.7 & 69005.88 \\
\hline 34 & $21 \mathrm{Jul} 20150245$ & 904.94 & 66326.91 \\
\hline 35 & $21 \mathrm{Jul} 20150250$ & 902.12 & 63007.54 \\
\hline 36 & $21 \mathrm{Jul} 20150255$ & 898.97 & 58404.44 \\
\hline 37 & $21 \mathrm{Jul} 20150300$ & 895.99 & 54035 \\
\hline 38 & $21 \mathrm{Jul} 20150305$ & 893.06 & 49642.19 \\
\hline 39 & $21 \mathrm{Jul} 20150310$ & 890.35 & 45789.22 \\
\hline 40 & $21 \mathrm{Jul} 20150315$ & 887.76 & 42212.87 \\
\hline 41 & $21 \mathrm{Jul} 20150320$ & 885.31 & 38952.82 \\
\hline 42 & $21 \mathrm{Jul} 20150325$ & 882.79 & 35372.93 \\
\hline 43 & $21 \mathrm{Jul} 20150330$ & 880.47 & 32440.87 \\
\hline 44 & $21 \mathrm{Jul} 20150335$ & 878.17 & 29578.76 \\
\hline 45 & $21 \mathrm{Jul} 20150340$ & 875.86 & 26768.61 \\
\hline 46 & $21 \mathrm{Jul} 20150345$ & 873.4 & 23476.48 \\
\hline 47 & $21 \mathrm{Jul} 20150350$ & 869.89 & 15720.35 \\
\hline 48 & $21 \mathrm{Jul} 20150355$ & 867.88 & 10014.62 \\
\hline
\end{tabular}




\section{Continued}

\begin{tabular}{|c|c|c|c|}
\hline 49 & $21 \mathrm{Jul} 20150400$ & 866.07 & 6045.1 \\
\hline 50 & $21 \mathrm{Jul} 20150405$ & 864.64 & 3535.43 \\
\hline 51 & $21 \mathrm{Jul} 20150410$ & 863.21 & 1721.92 \\
\hline 52 & $21 \mathrm{Jul} 20150415$ & 862.64 & 1327.31 \\
\hline 53 & $21 \mathrm{Jul} 20150420$ & 862.09 & 898.59 \\
\hline 54 & $21 \mathrm{Jul} 20150425$ & 861.67 & 694.05 \\
\hline 55 & $21 \mathrm{Jul} 20150430$ & 861.89 & 886.06 \\
\hline 56 & $21 \mathrm{Jul} 20150435$ & 862.09 & 1047.58 \\
\hline 57 & $21 \mathrm{Jul} 20150440$ & 862.3 & 1205.06 \\
\hline 58 & $21 \mathrm{Jul} 20150445$ & 862.39 & 1251.99 \\
\hline 59 & $21 \mathrm{Jul} 20150450$ & 862.47 & 1306.7 \\
\hline 60 & $21 \mathrm{Jul} 20150455$ & 862.53 & 1359.26 \\
\hline 61 & $21 \mathrm{Jul} 20150500$ & 862.52 & 1356.58 \\
\hline 62 & $21 \mathrm{Jul} 20150505$ & 862.51 & 1332.41 \\
\hline 63 & $21 \mathrm{Jul} 20150510$ & 862.53 & 1352.1 \\
\hline 64 & $21 \mathrm{Jul} 20150515$ & 862.52 & 1347.25 \\
\hline 65 & $21 \mathrm{Jul} 20150520$ & 862.48 & 1308.87 \\
\hline 66 & $21 \mathrm{Jul} 20150525$ & 862.46 & 1287.09 \\
\hline 67 & $21 \mathrm{Jul} 20150530$ & 862.43 & 1261.57 \\
\hline 68 & $21 \mathrm{Jul} 20150535$ & 862.38 & 1220.29 \\
\hline 69 & $21 \mathrm{Jul} 20150540$ & 862.34 & 1184.29 \\
\hline 70 & $21 \mathrm{Jul} 20150545$ & 862.3 & 1153.84 \\
\hline 71 & $21 \mathrm{Jul} 20150550$ & 862.24 & 1105.64 \\
\hline 72 & $21 \mathrm{Jul} 20150555$ & 862.2 & 1070.1 \\
\hline 73 & $21 \mathrm{Jul} 20150600$ & 862.15 & 1031.57 \\
\hline 74 & $21 \mathrm{Jul} 20150605$ & 862.13 & 1028.98 \\
\hline 75 & $21 \mathrm{Jul} 20150610$ & 862.14 & 1043.06 \\
\hline 76 & $21 \mathrm{Jul} 20150615$ & 862.18 & 1070.46 \\
\hline 77 & $21 \mathrm{Jul} 20150620$ & 862.23 & 1109.82 \\
\hline 78 & $21 \mathrm{Jul} 20150625$ & 862.28 & 1152.61 \\
\hline 79 & $21 \mathrm{Jul} 20150630$ & 862.33 & 1200.05 \\
\hline 80 & $21 \mathrm{Jul} 20150635$ & 862.32 & 1169.85 \\
\hline 81 & $21 \mathrm{Jul} 20150640$ & 862.33 & 1180.37 \\
\hline 82 & $21 \mathrm{Jul} 20150645$ & 862.28 & 1145.93 \\
\hline 83 & $21 \mathrm{Jul} 20150650$ & 862.24 & 1107.26 \\
\hline 84 & $21 \mathrm{Jul} 20150655$ & 862.21 & 1083.91 \\
\hline 85 & $21 \mathrm{Jul} 20150700$ & 862.17 & 1056.29 \\
\hline 86 & $21 \mathrm{Jul} 20150705$ & 862.16 & 1048.39 \\
\hline
\end{tabular}




\section{Continued}

\begin{tabular}{|c|c|c|c|}
\hline 87 & $21 \mathrm{Jul} 20150710$ & 862.18 & 1063.81 \\
\hline 88 & $21 \mathrm{Jul} 20150715$ & 862.21 & 1093.6 \\
\hline 89 & $21 \mathrm{Jul} 20150720$ & 862.26 & 1135.72 \\
\hline 90 & $21 \mathrm{Jul} 20150725$ & 862.32 & 1184.81 \\
\hline 91 & $21 \mathrm{Jul} 20150730$ & 862.38 & 1237.38 \\
\hline 92 & $21 \mathrm{Jul} 20150735$ & 862.33 & 1186.78 \\
\hline 93 & $21 \mathrm{Jul} 20150740$ & 862.31 & 1159.45 \\
\hline 94 & $21 \mathrm{Jul} 20150745$ & 862.28 & 1138.83 \\
\hline 95 & $21 \mathrm{Jul} 20150750$ & 862.21 & 1081.49 \\
\hline 96 & $21 \mathrm{Jul} 20150755$ & 862.19 & 1065.51 \\
\hline 97 & $21 \mathrm{Jul} 20150800$ & 862.22 & 1098.28 \\
\hline 98 & $21 \mathrm{Jul} 20150805$ & 862.24 & 1125.08 \\
\hline 99 & $21 \mathrm{Jul} 20150810$ & 862.27 & 1154.2 \\
\hline 100 & $21 \mathrm{Jul} 20150815$ & 862.32 & 1189.79 \\
\hline 101 & $21 \mathrm{Jul} 20150820$ & 862.36 & 1203.24 \\
\hline 102 & $21 \mathrm{Jul} 20150825$ & 862.39 & 1239.8 \\
\hline 103 & $21 \mathrm{Jul} 20150830$ & 862.34 & 1189.02 \\
\hline 104 & $21 \mathrm{Jul} 20150835$ & 862.34 & 1185.65 \\
\hline 105 & $21 \mathrm{Jul} 20150840$ & 862.32 & 1180.21 \\
\hline 106 & $21 \mathrm{Jul} 20150845$ & 862.26 & 1115.59 \\
\hline 107 & $21 \mathrm{Jul} 20150850$ & 862.25 & 1116.69 \\
\hline 108 & $21 \mathrm{Jul} 20150855$ & 862.2 & 1077.62 \\
\hline 109 & $21 \mathrm{Jul} 20150900$ & 862.16 & 1045.45 \\
\hline 110 & $21 \mathrm{Jul} 20150905$ & 862.16 & 1047.28 \\
\hline 111 & 21 Jul 20150910 & 862.17 & 1062.06 \\
\hline 112 & $21 \mathrm{Jul} 20150915$ & 862.2 & 1091.1 \\
\hline 113 & $21 \mathrm{Jul} 20150920$ & 862.26 & 1135.14 \\
\hline 114 & $21 \mathrm{Jul} 20150925$ & 862.33 & 1193.92 \\
\hline 115 & $21 \mathrm{Jul} 20150930$ & 862.41 & 1262.85 \\
\hline 116 & $21 \mathrm{Jul} 20150935$ & 862.4 & 1239.02 \\
\hline 117 & $21 \mathrm{Jul} 20150940$ & 862.39 & 1234.2 \\
\hline 118 & 21 Jul 20150945 & 862.38 & 1228.04 \\
\hline 119 & 21 Jul 20150950 & 862.33 & 1179.25 \\
\hline 120 & $21 \mathrm{Jul} 20150955$ & 862.32 & 1168.09 \\
\hline 121 & $21 \mathrm{Jul} 20151000$ & 862.28 & 1142.63 \\
\hline 122 & $21 \mathrm{Jul} 20151005$ & 862.23 & 1090.23 \\
\hline 123 & $21 \mathrm{Jul} 20151010$ & 862.2 & 1074.96 \\
\hline 124 & $21 \mathrm{Jul} 20151015$ & 862.21 & 1087.06 \\
\hline
\end{tabular}




\section{Continued}

\begin{tabular}{|c|c|c|c|}
\hline 125 & $21 \mathrm{Jul} 20151020$ & 862.25 & 1124.84 \\
\hline 126 & $21 \mathrm{Jul} 20151025$ & 862.31 & 1179.77 \\
\hline 127 & $21 \mathrm{Jul} 20151030$ & 862.39 & 1257.12 \\
\hline 128 & $21 \mathrm{Jul} 20151035$ & 862.5 & 1343.31 \\
\hline 129 & $21 \mathrm{Jul} 20151040$ & 862.49 & 1329.45 \\
\hline 130 & $21 \mathrm{Jul} 20151045$ & 862.48 & 1303.25 \\
\hline 131 & $21 \mathrm{Jul} 20151050$ & 862.51 & 1332.42 \\
\hline 132 & $21 \mathrm{Jul} 20151055$ & 862.5 & 1334.69 \\
\hline 133 & $21 \mathrm{Jul} 20151100$ & 862.48 & 1303.78 \\
\hline 134 & $21 \mathrm{Jul} 20151105$ & 862.48 & 1308.06 \\
\hline 135 & $21 \mathrm{Jul} 20151110$ & 862.48 & 1314.37 \\
\hline 136 & $21 \mathrm{Jul} 20151115$ & 862.46 & 1292.16 \\
\hline 137 & $21 \mathrm{Jul} 20151120$ & 862.45 & 1280.61 \\
\hline 138 & $21 \mathrm{Jul} 20151125$ & 862.45 & 1283.41 \\
\hline 139 & $21 \mathrm{Jul} 20151130$ & 862.43 & 1264.07 \\
\hline 140 & $21 \mathrm{Jul} 20151135$ & 862.41 & 1244.88 \\
\hline 141 & $21 \mathrm{Jul} 20151140$ & 862.4 & 1240.62 \\
\hline 142 & $21 \mathrm{Jul} 20151145$ & 862.37 & 1214.39 \\
\hline 143 & $21 \mathrm{Jul} 20151150$ & 862.34 & 1188.82 \\
\hline 144 & $21 \mathrm{Jul} 20151155$ & 862.31 & 1169.88 \\
\hline 145 & $21 \mathrm{Jul} 20151200$ & 862.27 & 1129.77 \\
\hline 146 & $21 \mathrm{Jul} 20151205$ & 862.23 & 1100.87 \\
\hline 147 & $21 \mathrm{Jul} 20151210$ & 862.19 & 1064.1 \\
\hline 148 & $21 \mathrm{Jul} 20151215$ & 862.14 & 1029.75 \\
\hline 149 & $21 \mathrm{Jul} 20151220$ & 862.13 & 1027.37 \\
\hline 150 & $21 \mathrm{Jul} 20151225$ & 862.15 & 1043.77 \\
\hline 151 & $21 \mathrm{Jul} 20151230$ & 862.19 & 1076.16 \\
\hline 152 & $21 \mathrm{Jul} 20151235$ & 862.24 & 1122.85 \\
\hline 153 & $21 \mathrm{Jul} 20151240$ & 862.3 & 1175.61 \\
\hline 154 & $21 \mathrm{Jul} 20151245$ & 862.37 & 1235.23 \\
\hline 155 & $21 \mathrm{Jul} 20151250$ & 862.35 & 1196.42 \\
\hline 156 & $21 \mathrm{Jul} 20151255$ & 862.35 & 1200.81 \\
\hline 157 & $21 \mathrm{Jul} 20151300$ & 862.32 & 1179.43 \\
\hline 158 & $21 \mathrm{Jul} 20151305$ & 862.27 & 1123.38 \\
\hline 159 & $21 \mathrm{Jul} 20151310$ & 862.25 & 1119.95 \\
\hline 160 & $21 \mathrm{Jul} 20151315$ & 862.21 & 1076.61 \\
\hline 161 & $21 \mathrm{Jul} 20151320$ & 862.17 & 1047.88 \\
\hline 162 & $21 \mathrm{Jul} 20151325$ & 862.15 & 1046.01 \\
\hline
\end{tabular}




\section{Continued}

\begin{tabular}{|c|c|c|c|}
\hline 163 & $21 \mathrm{Jul} 20151330$ & 862.13 & 1028.99 \\
\hline 164 & $21 \mathrm{Jul} 20151335$ & 862.15 & 1044.51 \\
\hline 165 & $21 \mathrm{Jul} 20151340$ & 862.21 & 1091.86 \\
\hline 166 & $21 \mathrm{Jul} 20151345$ & 862.27 & 1148.86 \\
\hline 167 & $21 \mathrm{Jul} 20151350$ & 862.34 & 1209.6 \\
\hline 168 & $21 \mathrm{Jul} 20151355$ & 862.38 & 1226.66 \\
\hline 169 & $21 \mathrm{Jul} 20151400$ & 862.36 & 1210.76 \\
\hline 170 & $21 \mathrm{Jul} 20151405$ & 862.33 & 1177.06 \\
\hline 171 & $21 \mathrm{Jul} 20151410$ & 862.31 & 1166.62 \\
\hline 172 & $21 \mathrm{Jul} 20151415$ & 862.26 & 1127.03 \\
\hline 173 & $21 \mathrm{Jul} 20151420$ & 862.23 & 1093.34 \\
\hline 174 & $21 \mathrm{Jul} 20151425$ & 862.18 & 1062.21 \\
\hline 175 & $21 \mathrm{Jul} 20151430$ & 862.17 & 1058.16 \\
\hline 176 & $21 \mathrm{Jul} 20151435$ & 862.18 & 1067.52 \\
\hline 177 & $21 \mathrm{Jul} 20151440$ & 862.22 & 1099.26 \\
\hline 178 & $21 \mathrm{Jul} 20151445$ & 862.27 & 1148.97 \\
\hline 179 & $21 \mathrm{Jul} 20151450$ & 862.35 & 1213.32 \\
\hline 180 & $21 \mathrm{Jul} 20151455$ & 862.45 & 1299.9 \\
\hline 181 & $21 \mathrm{Jul} 20151500$ & 862.42 & 1268.58 \\
\hline 182 & $21 \mathrm{Jul} 20151505$ & 862.39 & 1226.67 \\
\hline 183 & $21 \mathrm{Jul} 20151510$ & 862.37 & 1214.51 \\
\hline 184 & $21 \mathrm{Jul} 20151515$ & 862.3 & 1150.46 \\
\hline 185 & $21 \mathrm{Jul} 20151520$ & 862.25 & 1108.2 \\
\hline 186 & $21 \mathrm{Jul} 20151525$ & 862.2 & 1075.34 \\
\hline 187 & $21 \mathrm{Jul} 20151530$ & 862.19 & 1073.29 \\
\hline 188 & $21 \mathrm{Jul} 20151535$ & 862.2 & 1080.63 \\
\hline 189 & $21 \mathrm{Jul} 20151540$ & 862.22 & 1096.19 \\
\hline 190 & $21 \mathrm{Jul} 20151545$ & 862.24 & 1112.64 \\
\hline 191 & $21 \mathrm{Jul} 20151550$ & 862.25 & 1123.59 \\
\hline 192 & $21 \mathrm{Jul} 20151555$ & 863.37 & 2381.78 \\
\hline 193 & $21 \mathrm{Jul} 20151600$ & 862.82 & 1589 \\
\hline 194 & $21 \mathrm{Jul} 20151605$ & 862.31 & 1099.21 \\
\hline 195 & $21 \mathrm{Jul} 20151610$ & 861.8 & 728 \\
\hline 196 & $21 \mathrm{Jul} 20151615$ & 862.05 & 1012.11 \\
\hline 197 & $21 \mathrm{Jul} 20151620$ & 862.28 & 1194.19 \\
\hline 198 & $21 \mathrm{Jul} 20151625$ & 862.31 & 1177.16 \\
\hline 199 & $21 \mathrm{Jul} 20151630$ & 862.38 & 1226.16 \\
\hline 200 & $21 \mathrm{Jul} 20151635$ & 862.41 & 1263.36 \\
\hline
\end{tabular}




\section{Continued}

\begin{tabular}{|c|c|c|c|}
\hline 201 & $21 \mathrm{Jul} 20151640$ & 862.38 & 1224.19 \\
\hline 202 & $21 \mathrm{Jul} 20151645$ & 862.38 & 1217.55 \\
\hline 203 & $21 \mathrm{Jul} 20151650$ & 862.37 & 1223.18 \\
\hline 204 & $21 \mathrm{Jul} 20151655$ & 862.32 & 1170.33 \\
\hline 205 & $21 \mathrm{Jul} 20151700$ & 862.31 & 1161.47 \\
\hline 206 & $21 \mathrm{Jul} 20151705$ & 862.27 & 1139.17 \\
\hline 207 & $21 \mathrm{Jul} 20151710$ & 862.22 & 1086.68 \\
\hline 208 & $21 \mathrm{Jul} 20151715$ & 862.19 & 1072.51 \\
\hline 209 & $21 \mathrm{Jul} 20151720$ & 862.2 & 1081.97 \\
\hline 210 & $21 \mathrm{Jul} 20151725$ & 862.23 & 1109.48 \\
\hline 211 & $21 \mathrm{Jul} 20151730$ & 862.28 & 1156.86 \\
\hline 212 & $21 \mathrm{Jul} 20151735$ & 862.35 & 1218.86 \\
\hline 213 & $21 \mathrm{Jul} 20151740$ & 862.44 & 1294.82 \\
\hline 214 & $21 \mathrm{Jul} 20151745$ & 862.43 & 1274.2 \\
\hline 215 & $21 \mathrm{Jul} 20151750$ & 862.43 & 1262.98 \\
\hline 216 & $21 \mathrm{Jul} 20151755$ & 862.43 & 1273.18 \\
\hline 217 & $21 \mathrm{Jul} 20151800$ & 862.41 & 1248.9 \\
\hline 218 & $21 \mathrm{Jul} 20151805$ & 862.38 & 1218.84 \\
\hline 219 & $21 \mathrm{Jul} 20151810$ & 862.37 & 1213.7 \\
\hline 220 & $21 \mathrm{Jul} 20151815$ & 862.33 & 1179.16 \\
\hline 221 & $21 \mathrm{Jul} 20151820$ & 862.29 & 1147.73 \\
\hline 222 & $21 \mathrm{Jul} 20151825$ & 862.26 & 1127.75 \\
\hline 223 & $21 \mathrm{Jul} 20151830$ & 862.21 & 1076.81 \\
\hline 224 & $21 \mathrm{Jul} 20151835$ & 862.17 & 1053.97 \\
\hline 225 & $21 \mathrm{Jul} 20151840$ & 862.18 & 1066.78 \\
\hline 226 & $21 \mathrm{Jul} 20151845$ & 862.22 & 1098.79 \\
\hline 227 & 21 Jul 20151850 & 862.28 & 1155.3 \\
\hline 228 & $21 \mathrm{Jul} 20151855$ & 862.36 & 1224.7 \\
\hline 229 & $21 \mathrm{Jul} 20151900$ & 862.47 & 1322.62 \\
\hline 230 & $21 \mathrm{Jul} 20151905$ & 862.5 & 1320.88 \\
\hline 231 & $21 \mathrm{Jul} 20151910$ & 862.53 & 1354.27 \\
\hline 232 & 21 Jul 20151915 & 862.53 & 1351.68 \\
\hline 233 & $21 \mathrm{Jul} 20151920$ & 862.49 & 1319.85 \\
\hline 234 & $21 \mathrm{Jul} 20151925$ & 862.48 & 1309.08 \\
\hline 235 & $21 \mathrm{Jul} 20151930$ & 862.48 & 1313.05 \\
\hline 236 & $21 \mathrm{Jul} 20151935$ & 862.46 & 1290.38 \\
\hline 237 & $21 \mathrm{Jul} 20151940$ & 862.44 & 1272.48 \\
\hline 238 & $21 \mathrm{Jul} 20151945$ & 862.43 & 1270.89 \\
\hline
\end{tabular}




\section{Continued}

\begin{tabular}{llcc}
\hline 239 & 21 Jul 2015 1950 & 862.41 & 1249.49 \\
240 & 21 Jul 2015 1955 & 862.38 & 1224.21 \\
241 & 21 Jul 2015 2000 & 862.37 & 1213.65 \\
242 & 21 Jul 2015 2005 & 862.33 & 1184.37 \\
243 & 21 Jul 2015 2010 & 862.3 & 1154.22 \\
244 & 21 Jul 2015 2015 & 862.27 & 1129.64 \\
245 & 21 Jul 2015 2020 & 862.22 & 1086.4 \\
246 & 21 Jul 2015 2025 & 862.18 & 1055.84 \\
247 & 21 Jul 2015 2030 & 862.11 & 1005.7 \\
248 & 21 Jul 2015 2035 & 862.09 & 997.52 \\
249 & 21 Jul 2015 2040 & 862.1 & 1013.46 \\
\hline
\end{tabular}

